\title{
Multivariate hierarchical analyses of Early Jurassic Ostracoda assemblages
}

\author{
CARMEN ARIAS AND ROBIN C. WHATLEY
}

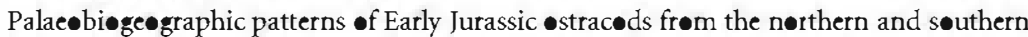
hemispheres (96 sections located in Eurøpe, North Africa, Western Australia and North

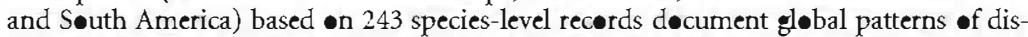

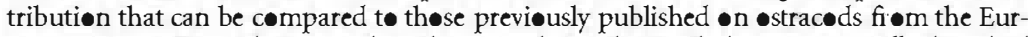
-pean Epicontinent Sea and Tethyan and S•uth Panthalassa areas. All described

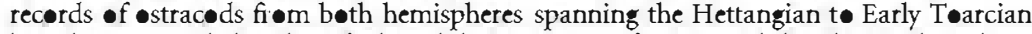
have been compiled and verified, and their patterns of origin and distribution have been interpreted. Jaccard coefficient of similarity was used to asses similarities ameng Eur-pean, American and Tethyan $\bullet$ strac $\bullet$ shelf faunas. The numerical analysis shøws a prgressive lengitudinal gradient in prøvincialism thrøugh the Early Jurassic, consistent

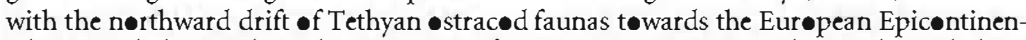

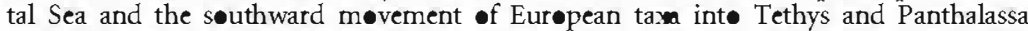
-ceans. The spread of cosmep litan species and extinction of endemic species, allied t• the disappearance of geographical barriers, warmer climate conditions and rising sea levels can explain the reduction in $\bullet$ straced diversity and the east-west prøvincialism throughøut the Early Jurassic. Interchange between hemispheres, including bip lar dis-

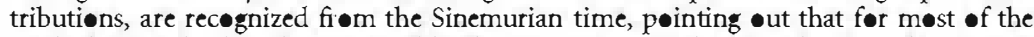
studied periød, the climate worldwide was warm and tropical. $\square$ Early Jurassic, European Epicontinental Sea, ostracod, palaeobiogeography, palaeoceanography.
\end{abstract}

Carmen Arias, [cariasf@geo.ucm.es], Departamento de Paleontología e Instituto de Geología Económica, (CSIC-UCM), Facultad de Ciencias Geológicas, UCM, Juan Antonio Novais, 2, 28040-Madrid, Spain; Robin C. Whatley, Micropalaeontology Research, Institute of Earth Studies, University of Wales, Aberystwyth, ofed SY23 3DB, UK:

The study of Early Jurassic provincialism has focussed on few invertebrate groups, especially ammonoids, brachiopods and bivalves (Donovan 1967; Géczy 1973, 1984, 1985; Enay 1980; Dommergues 1982; Enay \& Mangold 1982; Hallam 1984a; Crame 1986, 1991; Doyle 1987; Ziegler 1988, 1991, 1992; Riccardi 1991; Damborenea 1993). For a long time, the particular interest in this interval (from Hettangian to Toarcian) has been a reflection of the strong provincialism represented by the separation of Tethyan and Boreal provinces (Neumayr 1882, 1883; Uhlig 1911; Arkell 1956; Gordon 1970; Hallam 1975, 1983, 1984a; Bate 1977; Enay 1980; Copestake \& Johnson 1984; Cariou et al. 1985; Liu et al. 1998). Since the 1970s it has become clear that various microfossil biogeographic provinces could also be distinguished (Gordon 1970; Bate 1977; Lord 1982, 1988; Herrig 1988; Whatley 1988; Bucefalo-Palliani \& Riding 2003; Van de Schootbrugge et al. 2005).

The first tentative suggestion of the existence of Jurassic ostracod provincialism is that proposed by Bate (1977), who recognized five provinces based on the distribution of the Early Jurassic Ostracoda: the European, Tethyan, North African, American Province and East African. The European Province expanded from Newfoundland to the Ukraine and from Greenland to the northern margin of the Tethys area, including the Iberian Peninsula. The Tethyan Province extended from eastern Canada to North-West Africa. The palaeobiogeography of Early Jurassic ostracods of southern Europe is much less clear, because this latter province has a less complete record and its existence is more difficult to establish at least during this period. A recent study demonstrates an important change in Early Jurassic ostracod provincialism (Arias 2007b) and shows that provincialism was only outstanding from the Hettangian to middle Toarcian. It is not possible, however, to distinguish between the European and Tethyan provinces, at least since the Serpentinus Zone (Toarcian), because no particular ostracod species is present in only one ostracod province.

The aim of the present paper is to discuss: (1) the similarity between European, American, African and 
Western Australian ostracod assemblages; (2) to compare the marked ostracod provincialism with the provincialism of variøus fossil coups; and (3) to relate ostracod distribution patterns to palaeoclimatic and palaenemlogical conditions.

\section{Materials and methods}

Before the distribution pattern of the different $\bullet$ stracod taxa can be analysed, knowledge of the palaengeoraphy is required. In the most generally accepted reconstructions, we see a world dominated by the presence of a single supercontinent, Pangea, surrounded by a iant $\bullet$ cean, the Panthalassa cean (Dewey et $a$. 1973; Biju-Duval. et al. 1977; Owen 1983; Dercourt et al. 1985; Ziegler 1988, 1991, 1992; Veevers 2004). This supercontinent comprised two large landmasses: -ne southem continent known as Gondwana (South Americe, Africa, India and Antarctica) and another northern continent called Laurasia (Europe, North Americe and Southeast Asia). At the beginning of Jurassic, the European continent, sited in central Laurasia (Fig. 1) was covered by an epicontinental sea with restricted basins among an archipelage of islands (Hsü 1971; Thierry 1976; Smith 1983; Cariøu et al. 1985; Bassoullet et al. 1991, 1992; Meister \&
Stamfly 2000; Ziegler et al. 2000). In order to examine ostracod palaeobiogeographical patterns, we focused -n 19 areas and 96 sections (Fig. 1, Table 1).

Much of the published literature dates from the last 30 years, and contains considerable duplintion. Thus, this work invelved a revision of each marine ostraced species, consider.ng only those species, which have been well illustrated in the literature, therefore avoiding doubts in their identification. For each Early Jurassic stage (Hettangian, Sinemurian, Pliensbachian and earliest Toarcian) we produced a similarity symmetrical matrix, following Q-mode analysis (Henderson \& Heron 1976; Keesey \& Whitaker 1976; Pieløu 1979; Janson \& Vegelius 1981; Digby \& Kempton 1987). Inequality in sampling effort can influence species occurrences and richness estimates, and consequently, this paper only works with species composition not species richness. Following this intention, Jaccard's similarity coefficient (Jaccard 1912) was chosen because: (1) it ranges from zer t॰ -ne; (2) is independent of double absence; (3) emphasises presence instead of absence; and, (4) it not vulnerable to differences in sample size (Morisita 1959; Oeetham \& Hazel 1969; Go॰dall 1973, 1978; Gower 1975; Bareni-Urbani \& Buser 1976; Høhn 1976; Huhta 1979; Lamont \& Grant 1979; Wolda 1981; Hubalek 1982; Archer \& Mapples 1987, 1989;

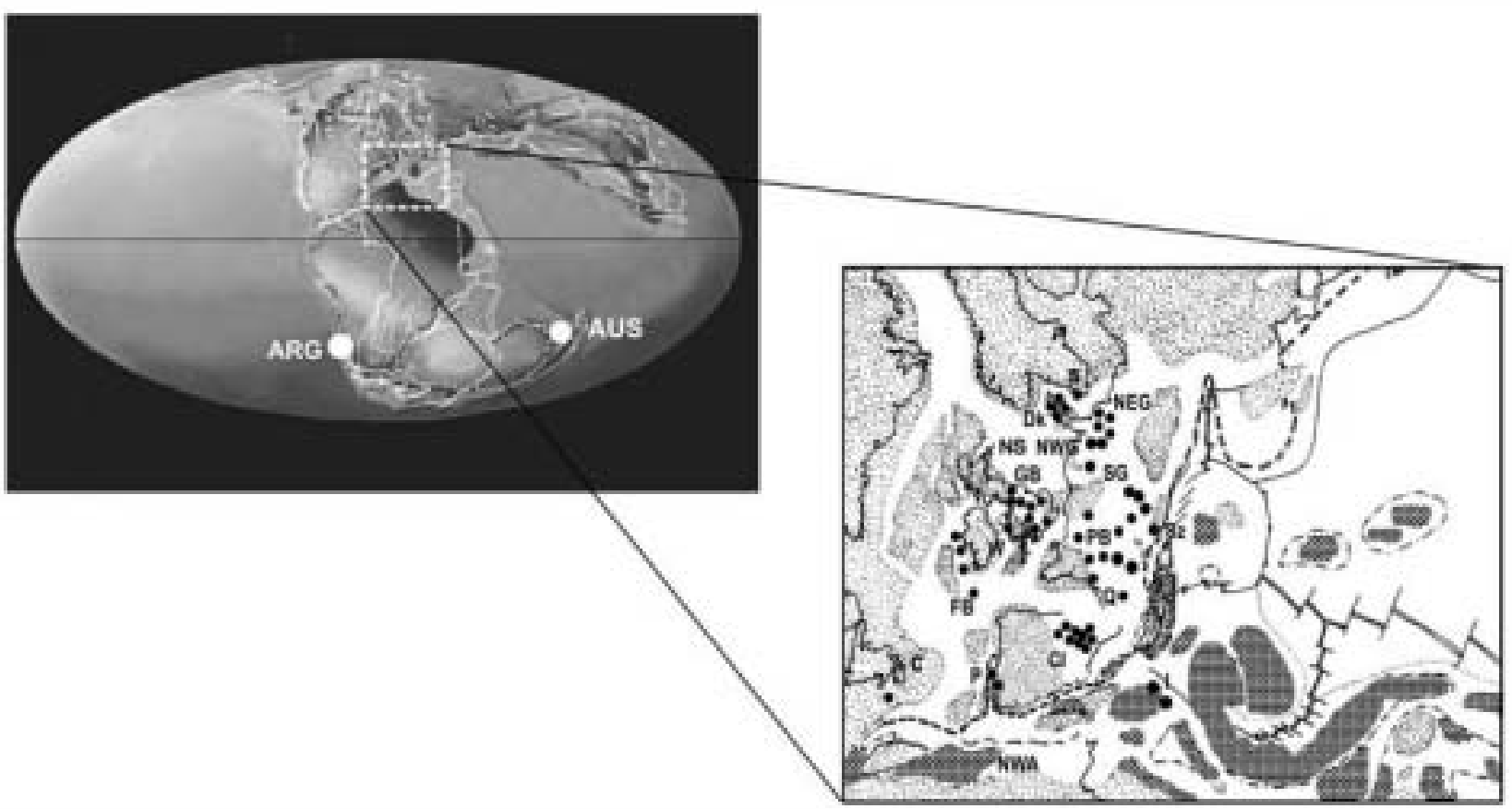

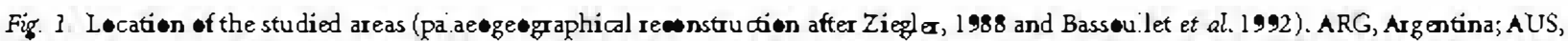
Westan Austraia; C, Canada; CI, Condilera Iberica; De, Denmark; FB, Fastuet Basin; GB, Grand Banks; I, Ita.y; NWA, Nerth West Africa; NEG, Northeast Germany; NS, North Sea; NWG, Northwest Germany; PB, The Paris Basin; P, Portuga.; Q, Quercy, Franee; SG, Søuthern Germany; S, Skone, Sweden; SZ, Swikerland; and, W, Waes (Plate tectenic maps and continenta. drift animations modified from Scotese (201). 


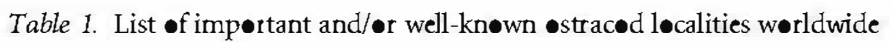

\begin{tabular}{|c|c|c|}
\hline Areas & References & Studied løcalities \\
\hline & Drexler 1958 & Siebeldingen (Rheinland-Pfalz) \\
\hline & Pietrzenuk 1961 & 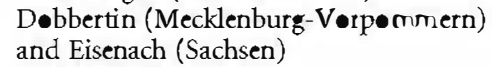 \\
\hline & Dreyer 1967 & Brandenburg \\
\hline \multirow{4}{*}{ Northeastern Germany (NEG) } & Herrig 1969a,b & Greifswald (Mecklenburg-V•rp•mmern) \\
\hline & Herrig 1979, 1980, 1981a,b,c, 1982a, b, 1985 & Thüringen \\
\hline & Triebel \& Bartenstein 1938 & Baden (Niedersachten) \\
\hline & Triebel \& Klingler 1959 & Hannever (Niedersachten) \\
\hline \multirow[t]{9}{*}{ Nortwestern Germany (NWG) } & Gramann 1963 & Weseker Sattel (Nordrhein-Wesfalen) \\
\hline & Malz 1971 & Niedersachten \\
\hline & Ohm (Fischer et al.), 1984 & Empelde (Niedersachten) \\
\hline & Fischer et al. 1986 & Hannøver (Niedersachten) \\
\hline & Fischer 1961a, b, 1962 & Baden-Württemberg \\
\hline & Klingler 1962 & Baden-Württemberg \\
\hline & Beher 2004; Beher et al. 2001 & Baden-Württemberg \\
\hline & Malz 1975 & Baden-Württember: \\
\hline & Knitter 1983,1984 & Baden-Württemberg \\
\hline \multirow{6}{*}{ S•uthwestern Germany (SWG) } & Knitter \& hmert 1983, 1986 & Baden-Württemberg \\
\hline & Knitter \& Riegraf 1984 & Baden-Württemberg \\
\hline & Riegraf 1984,1985 & Baden-Württemberg \\
\hline & Harl॰ff 1993 & Baden-Württemberg \\
\hline & Harløff \& Jäger 1994 & Baden-Württemberg \\
\hline & Beher 2004; Beher et al. 2001 & Søuthern Germany \\
\hline Canada (C) & Ext•n \& Gradstein 1984 & Grand Banks, Newf $\bullet$ undland \\
\hline \multirow[t]{3}{*}{ Celtic Sea-Fasnet Basin-P•rcupine (FB) } & Ainswørth 1986a, b, 1987, 1989 & Fasnet Basin \\
\hline & 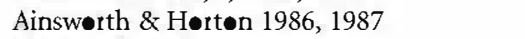 & Fasnet Basin \\
\hline & Ainsw•rth et al. 1987 & Fasnet Basin \\
\hline \multirow[t]{2}{*}{ Nørth Sea } & Malz \& Nagy 1989 & N•rth Sea \\
\hline & Ainswerth 1990 & P•rcupine, Slyne, Evris and D•negal \\
\hline Danish Embayment, Denmark (Dk) & Michelsen 1975 & Danish Embaymen \\
\hline \multirow{8}{*}{ Skane, S-uthern Sweden (S) } & Sivhed 1980 & Skane \\
\hline & Ap•st•lescu 1959, 1961 & Paris Basin \\
\hline & Ap•st•lescu et al 1961 & Paris Basin \\
\hline & Bizen 1960, 1961 & Basse Nermandie \\
\hline & Bizøn \& Oertli 1961 & Lerraine \\
\hline & C•usin \& Ap»st•lescu 1961 & Ardennes \\
\hline & Champeau 1961 & Paris Basin \\
\hline & Oertli $1961,1963,1985$ & Paris Basin \\
\hline \multirow[t]{10}{*}{ Paris Basin, France (PB) } & Oertli \& Gr @didier 1961 & Paris Basin \\
\hline & Magné \& Malmøustier 1961 & Thøuars \\
\hline & Magné et al. 1961 & Thøuars \\
\hline & Maupin 1978 & Vendee \\
\hline & Dêpeche 1985 & France \\
\hline & Denze 1985 & France \\
\hline & Riegraf 1985 & Truc de Balduc \\
\hline & Bødergat et al. 1991 & Paris Basin \\
\hline & 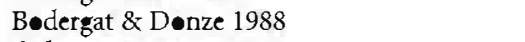 & Paris Basin \\
\hline & Cubaynes \& Faure 1981 & Quercy \\
\hline \multirow[t]{5}{*}{ Quercy, France (Q) } & Cubaynes 1986 & Quercy \\
\hline & Andreu et al. 1998 & Quercy \\
\hline & Cubaynes \& Ruget 1985 & Quercy \\
\hline & Lord $1974,1978,1988$ & Great Britain \\
\hline & Bate \& Coleman 1975 & England \\
\hline \multirow[t]{3}{*}{ Great Brimin (GB) } & 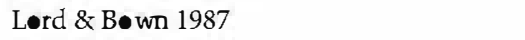 & Derset and Isle of Wight \\
\hline & B॰૯mer 1991 & Mechras, Wales \\
\hline & Be^mer 1992 & Ilminster, søuthwestern England \\
\hline \multirow[t]{3}{*}{ Italy (I) } & Lørd 1988 & Strettura \\
\hline & Arias 1993 & Umbria \\
\hline & Ext•n 1979 & Zambujal \\
\hline \multirow{2}{*}{ P•rtugal (P) } & Ext•n \& Gradstein 1984 & Zambujal \\
\hline & 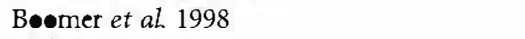 & Zambujal \\
\hline \multirow[t]{2}{*}{ nerthwestern Switzerland $(\mathrm{Sz})$} & Richter 1987 & Basel \\
\hline & Harl•ff \& Jäger 1994 & North Tyrel \\
\hline Argentina (ARG) & Ballent $1987,1991,1992$ & Neuquén \\
\hline Australia (AUS) & Lord et al. 1993 & Western Australia \\
\hline \multirow[t]{3}{*}{ Leg 79 , site 547 ( $\bullet$ ff-n๑rthern Africa) (NA) } & Bate et al. 1984 & Leg 79, site 547 \\
\hline & Arias 1989, 1991, 1995 & Cordillera Ibérica \\
\hline & Arias \& C Cmas-Rengif• 1992 & C•rdillera Ibérica \\
\hline Cordillera Iberica Spain (SP) & Arias et al. 1992 & Cordillera Ibérica \\
\hline & Arias \& Lørd 1999a,b & Cordillera Ibérica \\
\hline
\end{tabular}


Kenkel \& Booth 1987; Koch 1987; Magurran 1988; Mapples \& Archer 1988; Hengeveld 1990). Jaccard's Index is calculated by dividing the number of species found in both of two samples $(c)$ by the number found in only one sample and the other $(a$ and $b$ ) and then multiplying by 100 :

$$
\mathrm{JI}=\mathrm{c} /(\mathrm{a}+\mathrm{b}+\mathrm{c}) * 100
$$

where $\mathrm{c}$ is the number of species in common; $\mathrm{a}$ is the number of unique species to community 1 ; and $b$ is the number of unique species to community 2 .

This paper considers the agglomerative clustering method UPGMA (Unweighted Pair Group Method with Arithmetic mean) because it provides an unweighted arithmetic average between individuals (Hazel 1970; Anderber 1973; Sneath \& Sokal 1973; Everitt 1980; Romesbur 1984; Podam 1989; Shi \& Waterhouse 1990; Shi 1993). All analyses were done using the statistical software package NTsYs 2.02 (Rohlf 1997).

\section{Results}

The classification of the 19 areas analysed in terms of their similarities to the ostracod assemblages is shown in Figure 2A-D. For the Hettangian (Fig. 2A), the analysis shows two main groups that reveal a major separation between the north and central and the southern European faunas. With the exception of Western Australia, resemblances generally decreased as the deoghical distances to the Tethys Ocean increased. Considering this gradient of likenesses, we used two threshold values to discuss the groups formed at different levels. By using a conservative value of 0.30 similarities, a large group is formed that encompasses the Paris Basin, central England, Wales and southern Germany. Additionally one small group is distinguished, comprising Northeastern Germany and Portugal, which implies that the members of these pairs are equally similar to the Western European ostracod assemblages. Within the main group a compact core (British and the Paris basins) is differentiated, which is included by entities having similarities between them of at least 0.40 . Southern Germany is excluded from this core, thus it is the least related to the remaining entities, which constitutes central Europe. Contrary to our expectations based on our previous lnowledge of Portuguese fauna (Arias 1995) using this threshold we left Portugal out of the main group. The second group includes European area located on the northern margin of the European Epicontinental Sea (Danish Embayment, southern Sweden and the Fastnet Basin).
Similarities among studied assemblages for the Sinemurian are represented by the dendogram. Figure $2 \mathrm{~B}$ shows a division between all northern and central and southern European areas. The grouping of the analysed entities was notably modified when we used the highest similarity value (0.50). At this level, two well-defined groups are formed, and only the North Sea and Italian assemblazes remained as isolated entities. The main group, located in the upper section of the dendogram, comprises all entities located in northern (Swedish Danish, northern German assemblazes) and central European areas (southern Germany and the Paris Basin), which together correspond to the northeastern margin and central areas of the European Epicontinental Sea. The second group includes the British basins (as far north as the Fastnet Basin, as well as western British basins, both located on the northwestern margin of the European Epicontinental Sea), Quercy and Northwestern Africa basins (together situated on the southwestern margin of the European Epicontinental Sea). Surprisingly, Portuguese assemblages did not cluster with the second one (British Basin-Quercy-NW Africa), forming an independent group (Fig. 2B). Western Australia is associated to both clusters.

For the Pliensbachian (Fig. 2C) two major clusters were obtained. With the exceptions of Western Australia and Canada, similarities reduced as the spatial distances to central European Epicontinental Sea increased. Bearing in mind this similarity, we used two threshold values to examine the clusters formed at different ranks. By using the value of 0.40 similarity, an important group is formed that includes the Cordillera Ibérica (Spain), Quercy (southern France), Zambujal (Portugal) and the Fastnet Basin (southwest Ireland). Additionally two small groups are distinguished, one comprising the Cordillera IbericaQuercy, and the other, Portugal and Fastnet Basin. Within the main group a compact centre is differentiated, within which is included entities (Cordillera Ibérica and Quercy) having similarities between them of at least 0.78 . The other main group, located in the lower part of the dendogram, comprises all entities located in German and Danish basins, which correspond approximately to the northeastern margin of the European Epicontinental Sea. Contrary to our expectations, using this threshold left central England out of the both main groups and formed a free cluster related to the central and southwestern European assemblages, showing the high similarity values to the Cordillera Ibérica. Swiss (Sz) and Italian assemblages (I) are separated from the remaining areas. Canadian assemblages show a minimum similarity with the rest of studied area. The biotas of Western Australia and Argentina make up independent 
A

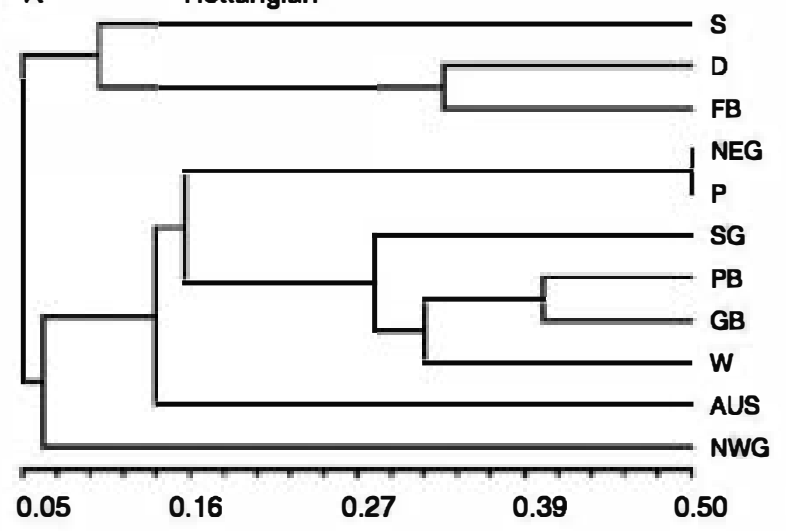

C

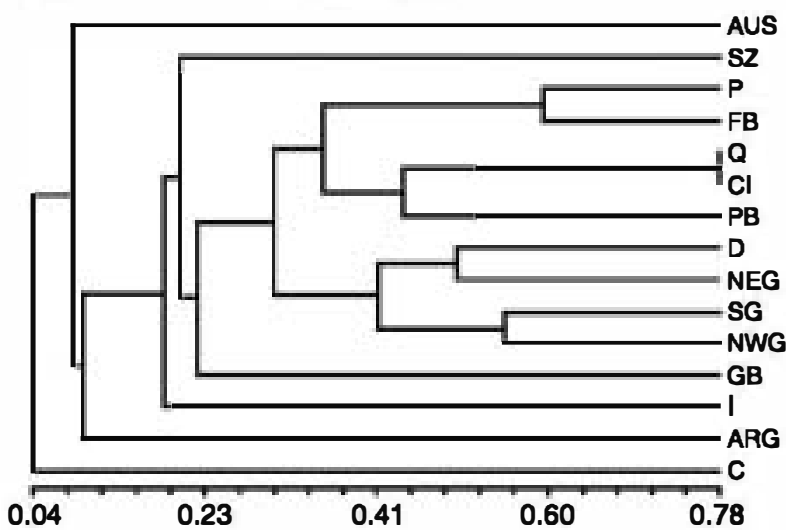

B

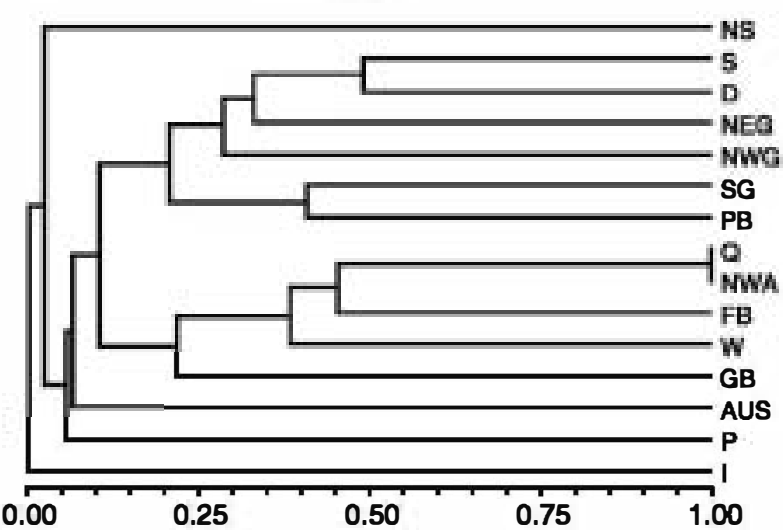

D

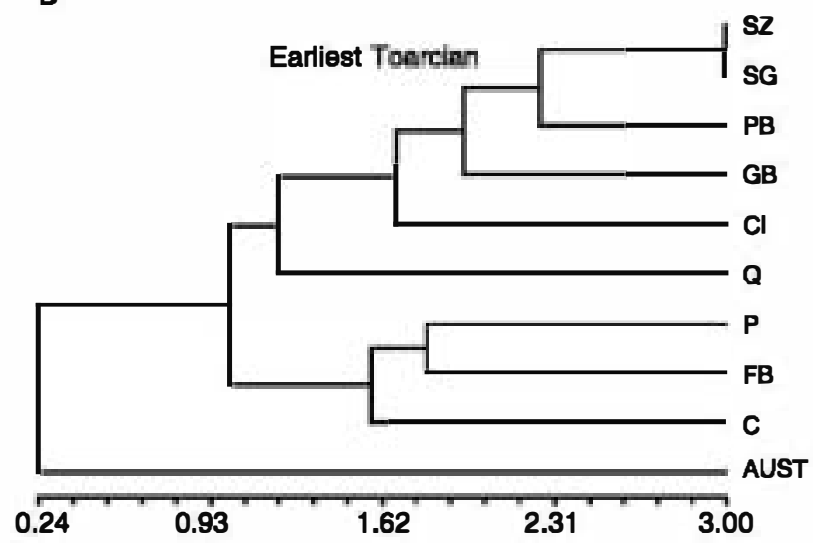

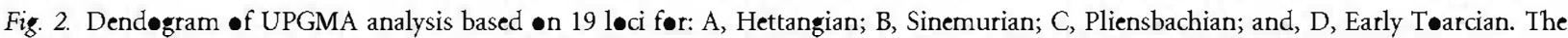
scale indicates the grade of similarity as determined with the Jaccard similarity coefficient. Abbreviations as in Figure 1.

branches. Argentinean faunas show higher values of similarity with European than Western Australian does (Fig. 2C).

The Western Australian area exhibited the lowest similarity relative to the rest of the sites during the earliest Toarcian (Fig. 2D). The first level shows two lare groups: one comprises the western and central European assemblages (Cordillera Ibérica, the Paris Basin, Quercy, southern Germany, Switzerland and central England), and the other group sites along the western margin of the European Epicontinental Sea comprise assemblages from Portugal, the Fastnet Basin and eastern Canada. The highest similarity within the central European areas was between southern German and Swiss assemblages, showing both the highest faunal similarity with central England. The areas of Zambujal, Portugal and the Fastnet Basin, in the western part of European Epicontinental Sea, form a group with considerably high similarity, and although are physically closest to the Cordillera Ibérica, they are included in a different cluster.
Finally, the Western Australia assemblages are the least similar to the European assemblages.

Compiling all the results demonstrates the evolution of the similarity between Early Jurassic ostracod assemblages. At the beginning of the Early Jurassic (Fig. 3A), the cluster analysis shows an initial division between northern and central European ostracod assemblages along the North Sea. This boundary during the Sinemurian (Fig. 3B) situates along a line, which passes through central Europe, between British and the Paris Basin and German areas. The main transformation took place during the Pliensbachian (Fig. 3C), with the boundary located between eastern (German and Danish basins) and western European basins (French and the Iberian Peninsula basins). The boundary is now located eastwards of the previously described position, with British assemblages maintaining as an independent group. During the earliest Toarcian, Tenuicostatum Zone, the boundary line experiences a distinctive westward movement and the Portuguese and the Fastnet Basin ostracod 

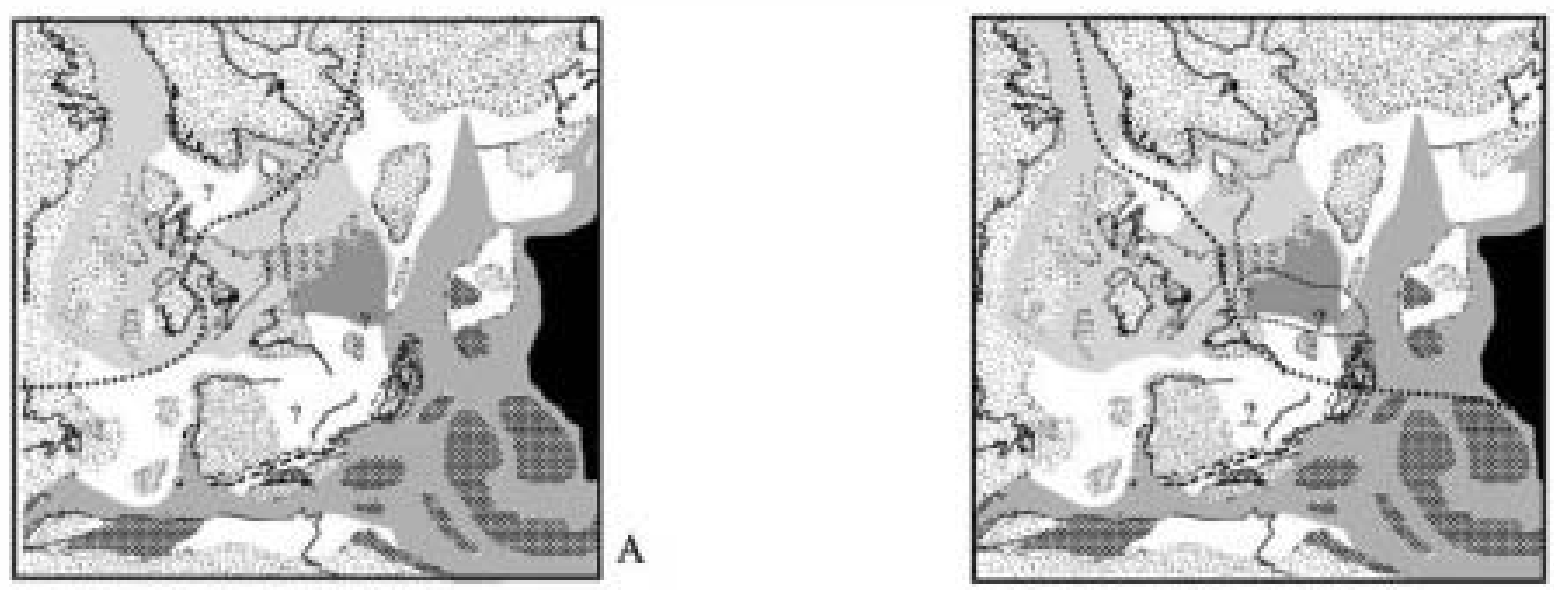

B

twu- Boundany between astracod assemblages
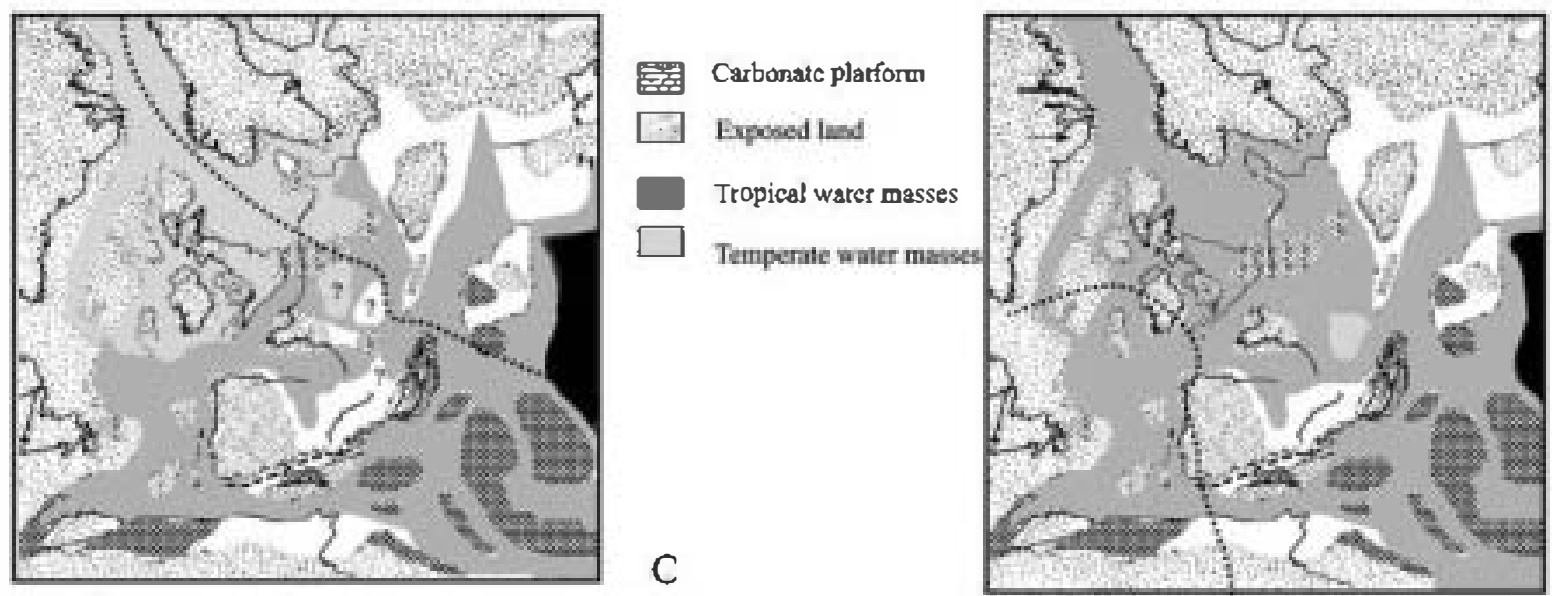

$\mathrm{D}$

Fig. 3. The position of the boundary among majer similarity clusters of ostracod assemblages. A, Hettangian; B, Simemurian; C) Pliensbachian; and, Early To arcian.

assemblages become an independent unit from the rest of European areas (Fig. 3D). The general results of the cluster analysis indicate a progressive translation of the border during the Early Jurassic.

\section{Discussion}

- Istraceda are tiny crustaceans, laterally compressed, enclosed within a bivalved carapace. Their longevity, renowned diversity $\bullet$ ff $\mathrm{rms}$ and limited dispersal capability make this group a potential source of the information on history of Early Jurassic seas. The majority - Early Jurassic ostracods wete neritic and most of them specialized in shallow-marine environments (Arias \& Whatley 2004). In a palaenecological perspective, ostracod palaeobiogeographers have used their patterns of distribution to infer the ecological role of several factors such as, depth, temperature, pH, light, etc. (Elofson 1941; Hallam 1969, 1978,
1985; Gorden 1970; Hazel 1970; Stevens 1973; Wøed \& Whatley 1994; Arias \& Whatley 2004).

The causes of palaeozøogeographical differentiation are complex and often difficult to understand. In order to elucidate the causes, both ecological and historical factors must be taken int acmunt, together with the phylogeny of the fossil group being studied. This is difficult for the Early Jurassic, because of our limited knowledge of the details of Jurassic marine environments. Evidence for unusually warm temperatures during the early Jurassic are frequently cited in palaeoclimatological, palaeontølogical and geological studies. In an ecological context, palaeobiogeographers have used spatial patterns of distribution to infer the ecological role of several fortors such as temperature, depth, pH, light, etc., (Arias \& Whatley 2004). Nevertheless, when we work on fossils, our considerations must incorperate new aspects, such as: palaengeographical reconstructions, phylogenetic relationships and those taphonomic processes that 
could have affected palaeobiogeographical results. In this study, the presence of different physical barriers (emerged lands, ocean currents, deep water and water chemistry), water temperature changes, sea level variations and changes in ocean circulation are considered as forcing agents of the palaeogeographical evolution during the Early Jurassic.

\section{Depth and water temperatures}

Benthonic ostracod species of the platform environments are characterized by their broad geographical ranges but show certain restriction in relation on the depth. Depth, in itself, is not the most important factor because its influence lies principally in its effect on other factors, such as, the water temperature, density or light intensity. Temperature has always been regarded as one of the most important factors in controlling the distribution of ostracod species (Whatley 1988) because it controls such factors of ostracod ecology, such as breeding season, abundance of individuals, food supply, size, etc.

Early Jurassic ostracod faunas reached their highest diversity in mid-shelf, warm-water tropical and subtropical environments, where shallow carbonates were deposited (i.e. the area between the line, which contains the Bohemian, the Rhenish-London-Brabant and the Iberian massifs, and the Irish Massif; or warm carbonate platforms along the northwestern African coast). Meanwhile deep-water clastic sequences, deposited at higher latitudes in cooler water settings (clastic deposits located between the Fennoscandian High and the Bohemian Massif; and the Lusitanian and the Fastnet basins) are characterized by lower diversity assemblages. This factor could partially explain why Irish and Portuguese ostracod assemblages form an independent cluster during the Pliensbachian-Toarcian transition (Arias 2007b).

Conventionally, the water temperature and salinity are considered as the major controlling factors on local distribution of invertebrate faunas (Donovan 1967; Gordon 1970, 1975; Howarth 1978; Brown 1988; Whatley 1988; Riccardi 1991; Rosenzweig 1995; Rohde 1998; Gaston 2000). Jurassic climate is characterized by being warmer and more equable than the present climate (Frakes 1979; Parrish 1982; Parrish \& Curtis 1982; Hallam 1984b, 1994; Frakes et al. 1992; Scotese 2001). These ideas are in disagreement with recent findings that suggest the occurrence of short cold episode during the Early Jurassic, particularly at the Pliensbachian-Toarcian transition (Rosales et al. 2004; van de Schootbrugge et al. 2005; Arias 2007a). Climate-sensitive sediment distribution (of such lithologies as coal, evaporite and carbonate) provides a particularly useful means of interpreting Early
Jurassic palaeoclimates (Robinson 1973; Gordon 1975; Frakes 1979; Parrish 1982; Hay et al. 1982; Manspeizer 1988; Frakes et al. 1992). Frakes et al. (1992) categorized Early Jurassic marine environments in a series of regional climate zones by integrating global lithological data distribution. Following this zonation, temperate and humid conditions would dominate across the northern mar in of the European Epicontinental Sea and Western Australia; subtropical climate conditions in the middle of the European Epicontinental Sea and southern Argentina; and tropical climate conditions along the North Africa coast and the Iberian Peninsula. Palaeontological proxies also confirm the existence of this equator-to-pole surface-temperature radient, with temperate water from European Epicontinental Sea and a subtropical and tropical Tethys Ocean (Vakhrameev 1964; Hallam 1972, 1975; Frakes 1979; Rees et al. 2000; Arias \& Whatley 2004; Arias 2007a, b).

Because the reliability of the available oxygen isotope measurements is questionable, climate simulations models have computer-generated sea surface temperature (Kutzbach \& Gallimore 1989; Chandler et al. 1992). Sea surface temperature simulations indicate the presence of warm polar waters (seasonal range between $3.5-9.5^{\circ} \mathrm{C}$ ), a low equator-to-pole temperature gradient of $22.2^{\circ} \mathrm{C}$, and an east-west equatorial temperature gradient (from $25^{\circ} \mathrm{C}$ in the eastern Panthalassa, to $32^{\circ} \mathrm{C}$ in the west Tethys). Climate models indicated that the European Epicontinental Sea was a tropical sea (with sea surface temperature of up to $25^{\circ} \mathrm{C}$ year round, reaching $15^{\circ} \mathrm{C}$ in autumn and less than $10^{\circ} \mathrm{C}$ in spring) and that Western Australia and Argentinean areas exhibited a similar sea surface temperature range $\left(18-24^{\circ} \mathrm{C}\right)$ (Kutzbach \& Gallimore 1989; Chandler et al. 1992). This thermal gradient across the central Pangaea is also explained by the development of the break-up of the supercontinent Pangaea, and the topography of the new proto-Atlantic rift (Gordon 1975; Manspeizer 1988). A result of this new topography, strong monsoonal conditions could have developed (Barron \& Washington 1982; Parrish \& Curtis 1982; Fleming 1983; Crowley et al. 1989; Kutzbach \& Gallimore 1989; Kutzbach, et al. 1990; Chandler, et al. 1992; Barron et al. 1994; Chandler 1994; Arias 2007a).

Therefore, the majority of Early Jurassic palaeoclimatic data show the existence of a latitudinal thermal gradient in both hemispheres. Ostracod assemblages seem to be confined to distinct biogeographical areas, reflecting water masses with a particular temperature regime, e.g. large, thick-shelled ornamented cytheroid dominate mid- and high-latitudes, meanwhile ornamented and smooth healdioids and bairdioids, and cytherellids prevail in low latitudes. Initially, this 
sharing out could correspond to temperate and warm-water ostracod faunas, respectively. However, the ostracod assemblages distribution is neither spatially constant nor shows a progressive latitudinal trend in the course of the Early Jurassic. If global temperature changes were fast and extreme, their effect would be to shift water masses and the associated ostracod faunas should move with them. Only the existence of a weak sea surface temperature latitudinal gradient from the Hettangian to earliest Toarcian in the European Epicontinental Sea might explain the non-existence of a latitudinal control over ostracod provincialism, the northward expansion of the warm Tethyan fauna to the more hostile unstable European Epicontinental Sea environment and the southward movement of European cytheroids. These movements could result in the combined presence of both assemblages across the whole European Epicontinental Sea and would explain the ostracod associations illustrated all through the Hettangian, Sinemurian and Pliensbachian similarity dendograms (Fig. 2A-C) and the lack of a latitudinal gradient, at least since the Sinemurian.

Therefore, Early Jurassic ostracod palaeobiogeography suggests that the water temperature was certainly a limited factor in the distribution of ostracods, although is difficult to demonstrate its effects. An increase of the environmental stability in the European Epicontinental Sea may explain why the Tethyan faunas did not had a limited northward during the Early Jurassic, the free movement of ostracod fauna across the whole studied area and the absence of a latitudinal provincialism. Although more information is needed in order to make interpretations less speculative, the effects of thermal variations in determining cycles of shrinking and expansion of the biogeographical distribution of ostracod diversity cannot be disregarded.

\section{Sea level changes and physical barriers}

The Jurassic was a time of major sea-level transgressions and regressions in both regional and global scales. Another important environmental factor for explaining ostracod movements is the sea-level change. Low stands reduce open seaways and spread of the ostracod faunas; meanwhile high sea levels facilitate faunal exchange, what would lead to an increase in overall diversity and extensive distribution of the fossil assemblages (Jablonski 1980; Meister \& Stamfly 2000). During the Early Jurassic, there was a transgressive trend with deepening episodes in the late Hettangian, mid-Sinemurian, latest Sinemurian, midPliensbachian, late Pliensbachian, mid-Toarcian and latest Toarcian (Vail et al. 1977; Hallam 1978, 1984a, 1988; Haq et al. 1987, 1988; Hardenbol et al. 1998; Meister \& Stamfli 2000; Gómez \& Goy 2002, 2005). These curves show episodic falls in sea level in the Late Triassic, Early Hettangian, Late Pliensbachian and mid-Toarcian (Vail et al. 1977; Hallam 1984a; Haq et al. 1987, 1988; Roth 1987; Hardenbol et al. 1998; Meister \& Stamfli 2000; Gómez \& Goy 2002, 2005). For the beginning the Jurassic, we recognize two main faunal clusters (Figs 2A, 3A). The boundary between both ostracod assemblages would set around the British Isles during the Hettangian. The limit moves eastward to reach central Europe during the Sinemurian (Fig. 3B) separating western (British basins) and central European (French and German basins) assemblages. A new eastward progress of the boundary shifts apart central (German basins) and northwestern European (British and French basins) ostracod assemblages during the Pliensbachian (Fig. 3C). Early Toarcian (Fig. 3D) reunites all European ostracod assemblages, but the most western extreme area (the Fastnet Basin, the western Portugal and the eastern Canada). Initially, it would be possible to relate all these movements, go forward and draw back, of the boundary with eustatic changes. Transgressive episodes could be linked to the eastward movement of the boundary (i.e. during the Sinemurian and Pliensbachian), and regressive episodes to the westward progress of the boundary (i.e. at the beginning of Toarcian). Thus, sea level changes could be a dominant factor controlling ostracod diversity and migration.

Explanations for the distribution pattern of marine ostracod include, in addition to changes in temperature and eustatic sea level, the presence or absence of physical barriers (such as landmasses or deep water) as potential factors governed the ostracod distribution by means of opening or closing of the communication routes between basins. Barriers, such as shallow carbonate platforms or emerged land belts along the southern part of the European Epicontinental Sea (i.e. the Briaconnais and Corso-Sardinia blocks or the Balears and Pre-Betic platforms), might have also acted as a barrier insulating the European Epicontinental Sea from the Tethys Ocean (Almeras \& Elmi 1987). Only a few areas (areas between the Lower Austroalpine and South Calcareous Alps; across the Balcony Mounts; the Burgundy area or between the Sub-Briaconnais and the Lower Austroalpine areas) may have worked temporally as a passage, at least from the Late Sinemurian to Pliensbachian (Dommergues \& Meister 1991; Meister \& Stamfly 2000). The opening of these interchanges seaways would be responsible for the north-south direction of the boundary during Sinemurian and Pliensbachian (Fig. 2B-D) and the pattern of ostracod migration 
(closest areas to these entrance areas, i.e. German, Swiss and French are very similar). The same can be said for the other entrance route, the Iberian-Moorish Strait, between North African and British basins during the Pliensbachian (Dommergues \& Mouterde 1980; Dommergues 1982; Enay \& Mangold 1982; Cariou et al. 1985), would explain the highest similarity among western European and African ostracod assemblages during the Pliensbachian (Fig. 2C).

However, the question remains as to why ostracods did not spread longitudinally. The answer could be the presence of physical barriers and seaways. For example, the opening of the Poitou Strait between the Aquitaine and Paris basins during the Late Pliensbachian (Gabilly 1976; Galbrun et al. 1994) not only facilitated a new access for faunal interchange between Quercy and the rest of central European basins but also would explain the similarity between French assemblages (the Paris Basin and Quercy) during the Pliensbachian-Toarcian boundary (Fig. 2C, D). Nevertheless, the most remarkable aspect of cluster results was that during the Pliensbachian (Fig. 2C), British assemblages maintained an independent position relative to the rest of central European areas and that German basins were shifted to French basins assemblages. The response would be the presence of some barrier around the London-Brabant Massif (Moreton-in-Marsh and Market-Weighton thresholds) that kept British basins in isolation, preventing faunal interchanges between northern German and southern British basins (Ager 1956; Donovan 1967; Howarth 1973; Mégnien 1980; Dommergues 1982; Enay \& Mangold 1982; Meister \& Stamfly 2000). Their posterior total opening would explain the westward movement of the boundary during the earliest Toarcian (Fig. 2D).

The most significant was the aperture of the Hispanic Corridor (Smith 1983), right through the present Strait of Panama, which could have allowed, since the Pliensbachian, the movement of European and Tethyan ostracod forms into the Panthalassa ocean (Damborenea 2000; Arias 2006). This new passage might explain a new generalized westward expansion of the western European Epicontinental Sea ostracod faunas to the Argentinean basins, southeast Panthalassa Ocean (Boomer \& Ballent 1996; Arias 2006), and could be the root for the minor cluster, which comprises Portuguese, Canadian and Irish ostracod assemblages during the earliest Toarcian (Fig. 2D).

\section{Water masses and ocean circulation change}

The importance of marine currents in governing faunal migration is out of doubt. Several authors have attempted to reconstruct the palaeocurrent patterns of the Jurassic oceans from the research on the rate and routes of fossil migration (Ager 1975; Enay 1980; Arias \& Whatley 2004; Arias 2007a). Palaeoceanographic models are presently the most used for simulating Early Jurassic ocean-surface circulation (Parrish \& Curtis 1982; Parrish et al. 1982; Crowley et al. 1989; Kutzbach \& Gallimore 1989; Kutzbach et al. 1990; Chandler et al. 1992; Barron et al. 1994; Chandler 1994; Scotese \& Summerhayes 1986; Arias 2007a) (Fig. 4A, B). Many authors have postulated the existence of Arctic/Boreal and Tethyan currents flowing in opposite directions currents, until they collided in the northern part of the European Epicontinental Sea contributing to the Boreal/Tethys provincialism (Ager 1975; Fürsich \& Sykes 1977; Arias 2007a). This collision of currents could cause the division outlined in the Figure 2A.

Arias (2007a) explained in the broader context of the European Epicontinental Sea deep oceanic circulation, the movements of European ostracods during the Pliensbachian-Toarcian boundary. She combined faunal, lithological, salinity and temperature distribution, proposing an integrated threefold classification of water masses (tropical, subtropical and temperate). In this model, the deep-water circulation would be of an estuarine type with warm water from the Tethys flowing northwards at depth to the European Epicontinental Sea and superficial cold and freshening water flowing out from the European Epicontinental Sea to the Tethys Ocean (Arias 2007a). As a result, the deep water filling the European Epicontinental Sea was warmer, what is reliable with estimated palaeotemperatures and the temperature gradient between the northern latitudes and the tropics. These environmental conditions allow the free movement of ostracod faunas through the European Epicontinental Sea, with the entry of Tethyan faunas along the southern margin of the European Epicontinental Sea and the southward movement of the European ostracod faunas (Fig. 5). The cluster analysis of the Early Jurassic ostracod faunas also reveals a high degree of similarity between South America, Australia and western and central Europe. Since Australian faunas are similar to central Europe assemblages, an open communication along the western Tethys, aided by eastward currents was suggested by Arias (2006). Ostracod assemblages from central Argentina show higher similarity to western European Epicontinental Sea (Portugal, Grand Banks, the Fastnet Basin, and Wales) and North Africa than to central European assemblages. This assumption would indicate an east-west migration of the European ostracod faunas across the Hispanic Corridor, since at least the Pliensbachian-Toarcian (Boomer \& Ballent 1996; Arias 2006). 
A
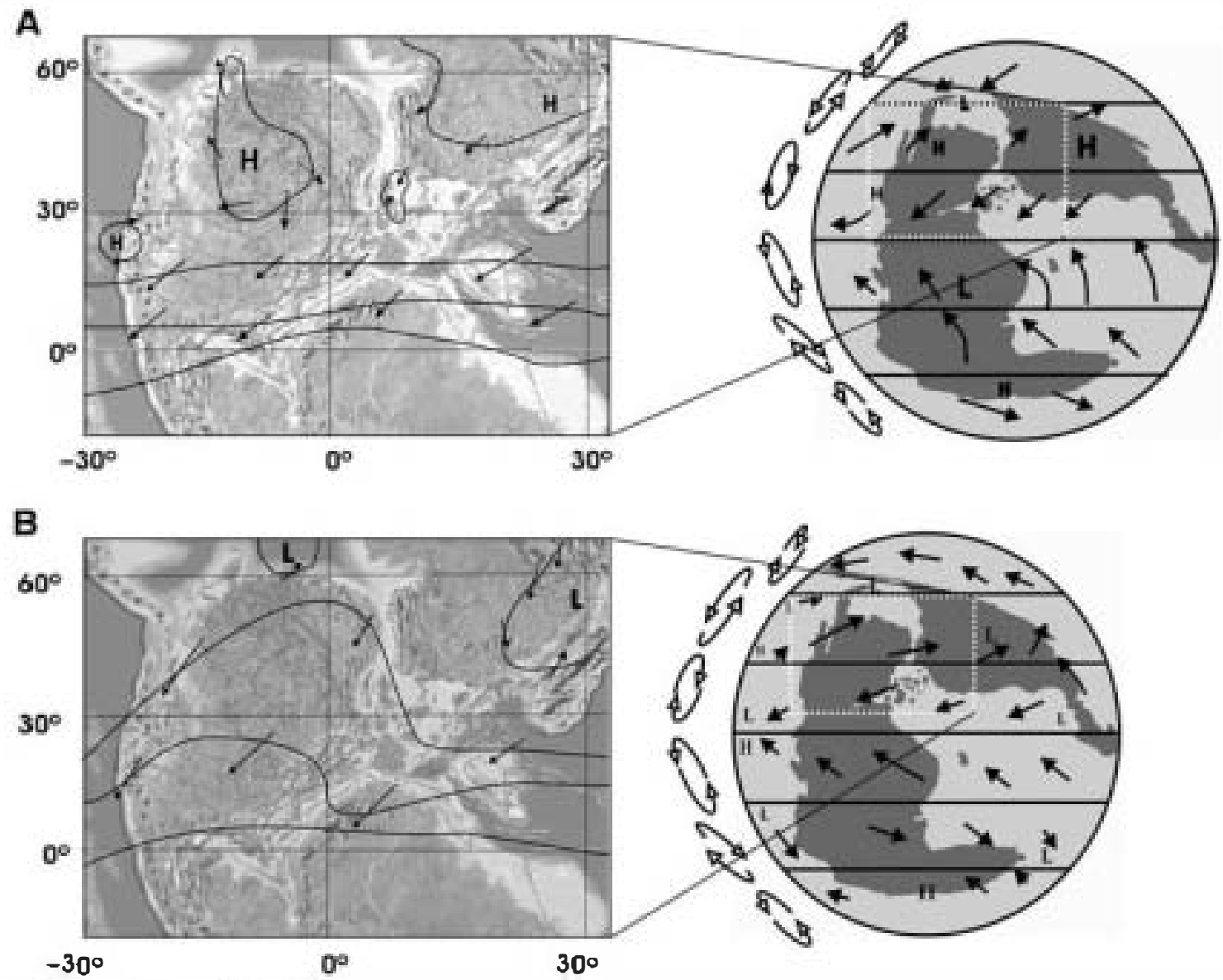

Fig. \& Early Jurassic atmoopharic ciralation in the northan Hamispbare. $A_{4}$ wintar and, B, summa.
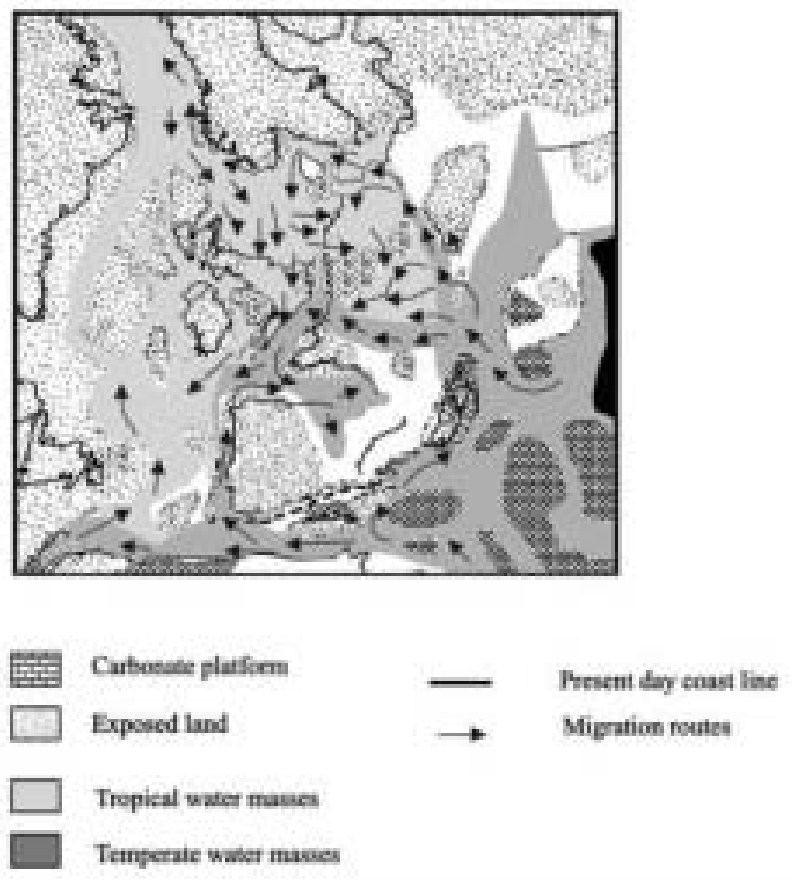

Fig. 5. Ostraced migration routes during the Early Jurassic pa.aegeographica. recenstruction modified from Scotese (2001).

\section{Conclusions}

The Early Jurassic was a time of an impertant marine faunal innovation that gave rise to the taxonomic prominence of several roups of mirofossils that played a major role in the early Jurassic oceans. Ostracoda are regarded as one the most important fossil groups for the palaeobiogeosaphy of the Early Jurassic, because they are characterized by being more cosmoplitan in distribution than ther important fossils, such as ammonoids or bivalves, which

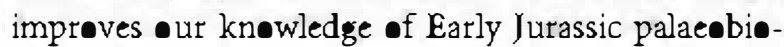
geography, palaenceanography and palaeeclimatel-gy. The faunal similarity among several regions of the European Epicontinental Sea, Tethys and Easter Panthalassa eceans illustrates the division of the Eur-pean Epicontinental Sea-Western Tethys area inte faunal regions. The cluster analysis showed an eastwest splitting up along the North Sea during the Hettangian; between British and central European basins (French and German basins) during the Sinemurian, and between German and French basins during the Pliensbachian. At the beginning of Toarcian, the 
boundary moved westward, falling apart the Western European Epicontinental Sea assemblages from the rest of European ostracod assemblages. The distributional limits of ostracod assemblages are set by its ecological attributes and historical factors (a certain water temperature control, sea-level changes, adjustment in physical barriers and changes in ocean circulation). In the present paper, the study of Early Jurassic ostracod palaeobiogeography and their palaeoecological requirements of the different types of Ostracoda under consideration allows us to explain the similarities among the ostracod faunas from Western European, Tethyan, South American and Australian basins.

Acknowledgments. - I thank Prøfess A. Crame and Dr Ian

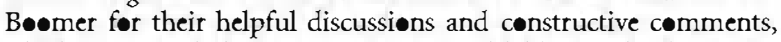
which improved the manuscript. I wøuld like to thank Dr Jan Audun Rasmussen of the Natural Museum of Denmark, Cøpenhagen, for their helpful discussions and constructive comments, and for taking the time t• comment on the several chapters, which imprøved the manuscript. Alsø I wøuld like t• thank Dr. Svend

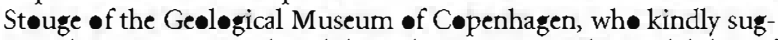
gested improvements that did much to augment the readability of the final manuscript. We gratefully acknowledge the immense help received from Professor Peter Doyle of UCL and the editors of Lethaia. The authørs would like to thank the five reviewers for their comments that help improve the manuscript. One of us (Carmen

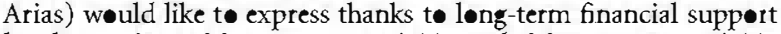
by the Prøjects CGL 2005-1765/BTE and CGL-2005-4574/BTE from the Ministeriø de Educación y Ciencia (Spain).

\section{References}

Ager, D.V. 1956: The geegraphical distribution of brachiop ds in the British Middle Lias. Quarterly Journal of the Geological Society of London 112, 157-187.

Ager, D.V. 1975: The Nature of the Stratigraphical Record. 114 pp.

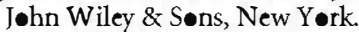

Ainswerth, N.R. 1986a: Rhaetian, Hettangian and Sinemurian -straceda from the Fastnet Basin, offshøre Søuthwest Ireland. Bulletin of the Geological Survey of Ireland 4, 107-150.

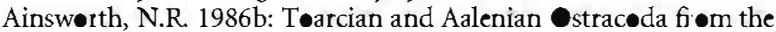
Fastnet Basin, offshøre søuth-west Ireland. Bulletin of the Geological Survey of Ireland 3, 277-336.

Ainswørth, N.R. 1987: Pliensbachian -straceda frøm the Fastnet Basin, -ffshøre søuth-west Ireland. Bulletin of the Geological Survey of Ireland 4, 41-62.

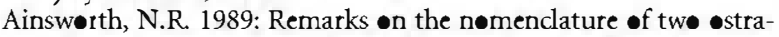
cød species fiem the Pliensbachian and upper Tøarcian-Aalenian $\bullet$ the Fastnet Basin, offshøre Søuthwest Ireland. Bulletin of the Geological Survey of Ireland 4, 165-166.

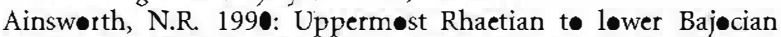

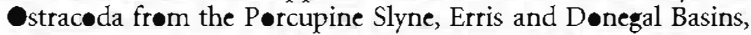
-ffshore west Ireland. Bulletin of the Geological Survey of Ireland 4, 169-200.

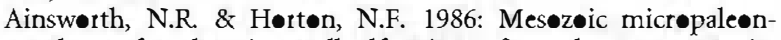

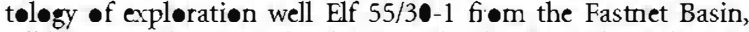
-ffshøre søuthwest Ireland. Journal of Micropaleontology 5, 19-29.

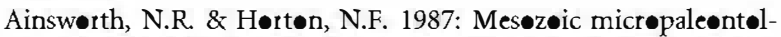

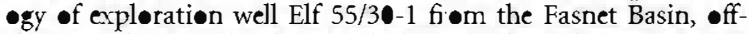
shøre søuthwest Ireland. Journal of Micropaleontology 5/1, 19-29.

Ainswørth, N.R., 'Neill, M., Rutherford, M.M., Clayt॰n, G., Hørt॰n, N.F. \& Penney, R.A. 1987: Biestratigraphy of the Løwer Cretaceous, Jurassic and uppermøst Triassic of the
Nerth Celtic Sea and Fastnet Basin. In Brøoks, J. \& Glennie, K. K. (eds): Petroleum Geology of North West Europe, 611-622.

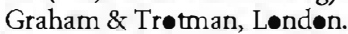

Almeras, Y. \& Elmi, S. 1987: Evolution des peuplements des brachiop des en fonction del' environnement dans le Lias ardéchøis. Cahiers Scientifiques de l' Université Catholique de Lyon 1, 21-56.

Anderberg, M.R. 1973: Chuster Analysis for Applications. 359 pp. Academic Press, New York.

Andreu, B., Bødergat, A.M., Brunel, F., Cølin, J.P. \& Cubaynes, R. 1998: -stracedes du Carixien supérieur-D•merien (Jurassique inférieur) du Quercy, Bassin d'Aquitaine, France. Palaeontographica, Abt A 250, 68-122.

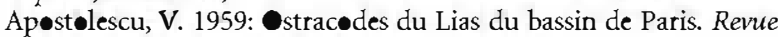
de l' Institute français de Pétrole 15, 795-817.

Apøstelescu, V. 1961: Sud du Bassin, Région D’Argentøn-surCreuse et de la Chatre (Départements du Cher et delà' Indre) -stracedes. In Riøult, M. \& Bizøn, J.J. (eds): Colloque sur le Lias français. Mérnorie Bureau Recherche Géologiques Minières 4, 445449. Technip, Paris.

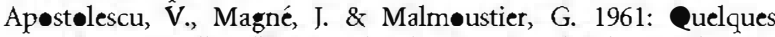
espèces nøuvelles d'stracedes du Tøarcien de Thøuars (DeuxSèvres). In Riøult, M. \& Bizøn, J.J. (eds): Colloque sur le Lias français. Mérnoire du Bureau de Recherche Géologiques et Minières 4, 399-415.

Archer, A.W. \& Mapples, C.G. 1987: Mønte Carlø simulation of selected bin॰mial similarity coefficients (I). Effect of number of variables. Palaios 2, 609-617.

Archer, A.W. \& Mapples, C.G. 1989: Mønte Carlø simulation of selected bin๑mial similarity coefficients (II). Effect $\bullet$ number of variables, comment and reply. Palaios 4, 101-103.

Arias, C. 1989: Los ostrácodos del Domeriense superior-Toarciense inferior de la Cordillera Ibérica. Unpub. MSc thesis, Fac. CC Geelogicas, Universidad Complutense de Madrid.

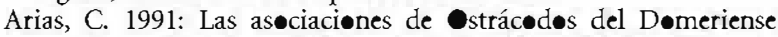
superior y Tøarciense inferior de la Cordillera Ibérica. Coloquios de Paleontología 43, 79-99.

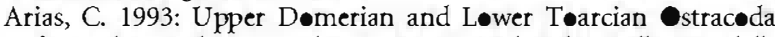
from the Umbria-Marche Basin, Central Italy. Bollettino della Societá Paleontologica Italiana 32, 367-383.

Arias, C. 1995: Los ostrácodos del Toarciense inferior en la Cordillera Ibérica. Unpublished Ph.D. thesis. Facultad de Ciencias Geelegicas, $521 \mathrm{pp}$. Universidad Complutense de Madrid, Madrid, Spain.

Arias, C. 2006: Nørthern and Søuthern Hemispheres •straced palae biogeography during the Early Jurassic: possible migration routes. Palaeogeography, Palaeoclimatology, Palaeoecology 233, 63-95.

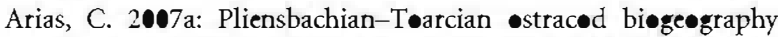
in NW Europe: evidence for water mass structure evolution. Palaeogeography, Palaeoclimatology, Palaeoecology 251, 398 421.

Arias, C. 2007b: Changes in estraced previncialism during the Early Toarcian in the Eurøpean Epicontinenwl Sea-Western Tethys area. Revista Española de Micropaleontologia 38, 245267.

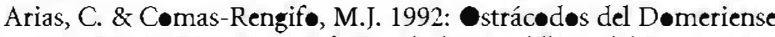
superior y Toarciense inferior de la Cordillera Ibérica. Revista Española de Micropaleontología XXIV, 111-155.

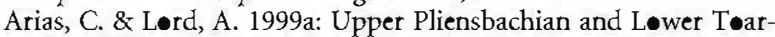
cian Ostraceda from the Cordillera Iberica, Northeast Spain part. 1: Revista Española de Micropaleontología 31, 73-98.

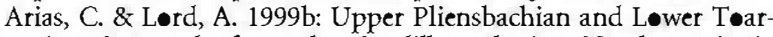
cian Ostraceda from the Cordillera Iberica, Northeast Spain part. 2: Revista Española de Micropaleontologia 31, 219-242.

Arias, C. \& Whatley, C. 2004: Distribution patterns of early Jurassic Straceda and possible communication routes through the European Epicontinental Sea, evidence of changes in $\bullet$ cean circulation patterns and its consequence t• climate change. Neues Jahrbuch fiur Geologie und Paläontologie Abhandlungen 232, 1-55.

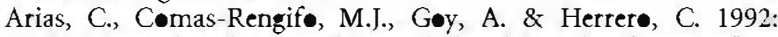
Variations dans les asseciations de brachiopøes, foraminiferes 


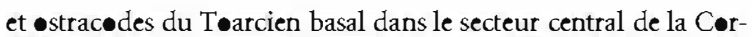
dillere Ibérique, un exemple dans La Rambla del Salt• Teruel, Espagne: Cahiers Scientifiques de l'Université Catholique de Lyon 5, 5-25.

Arkell, W.J. 1956: Jurassic of the World. 806 pp. Oliver and Bøyd, Edinburgh.

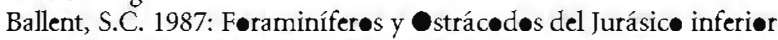
de Argentina. Revista del Museo de la Plata 9, 43-130.

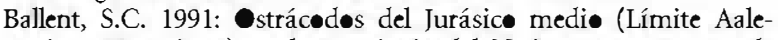

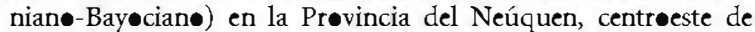
Argentina. Revista Española de Micropaleontología 23, 21-56.

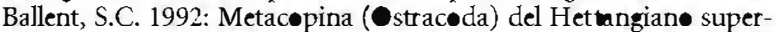
iør en el sudøeste de la prøvincia de Mendøza. Revista Española de Micropaleontología 29, 153-157.

Bar ni-Urbani, C. \& Buser, M.W. 1976: Similarity of binary data. Systematic Zoology 25, 251-59.

Barrøn, E. \& Washingten, W. 1982: Atmøspheric circulation during warm geologic periods, Is the equater to pøle surface temperature gradient the contrølling facter. Geology 10, 633-636.

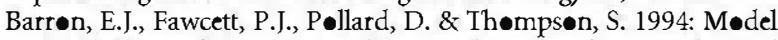
simulations of Cretaceous climates, the role of geography and

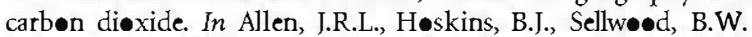
Spicer, R.A. \& Valdes, P.J. (eds): Palaeoclimate and their Modelling with Special Reference to the Mesozoic Era, 99-107 pp. Chapman \& Hall, Lønd $\bullet$.

Bassıullet, J.P., Lachkar, G.M., Baudin, F., Benshili, K., Blanc, P., Bøutakiout, M., Depeche, F., Elmi, S. \& Ruget, C. 1991: Stratigraphie intégrée dans le T•arcien du Marøc (rides sud rifaines et Møyen Atlas). Bulletin de la Société Géologique de France 162, 825-839.

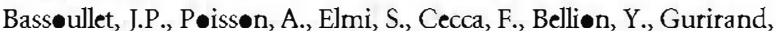
F. \& Baudin, F. 1992: Mid-T•arcian 184-182 m.a.: Tethys Pale• maps. In Dercourt, J., Ricœu, L.E. \& Vrielynck, B. (eds):Atlas Tethys of Paleoenvironmental Maps, $307 \mathrm{pp}$. Gauthier-Villars, Paris.

Bate, R.H. \& Cøleman, B.E. 1975: Upper Lias straceda fr Rutland and Huntingdenshire. Bulletin of the Geological Survey of Great Britain 55, 1-42.

Bate, R.H. 1977: Jurassic straceds of the Atlantic Basin. In Swain, F.M. (ed.): Stratigraphic Micropaleontology of the Atlantic Basins and Borderlands. Developmen in Palaeontology and Stratigraphy 6,231-242. Elsevier, Amsterdam.

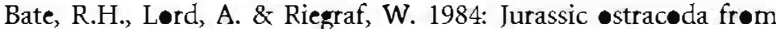
Leg 79, Site 547. Initial Repor of the Deep Sea Drilling Project $78,703-710$.

Beher, E. 2004: Astracedenfauna und Biostratigraphie im berSinemurium ven Süddeutschland und der Nordschweiz. Stuttgarter Beiträge zur Naturkunde. Serie B Geologie und Paläontoloie $B, 1-171$.

Beher, E., Franz, M. \& Schweizer, V. 2001 : Zur stracedenfauna des Ober-Sinemurium und untersten Pliensbachium im Gebiet vøn Tuningen (Baden-Wïrttemberg). Neues Jahrbuch fïr Geologie und Paläontologie, Abhandlungen 219, 329-391.

Biju-Duval, B., Derceurt, J. \& Le Pichøn, X. 1977: Frøm the Tethys -cean to the Mediterranean seas: a plate tectonic model of the evolution of the western alpine system. In Biju-Duval, B. \& Montadert, L. (eds): Histoire structurale des bassins méditerranéens, 143-164. Technip, Paris.

Bizøn, J.J. 1960: Sur quelque •stracedes du Lias du Bassin parisien. Revue de Micropaléontologie 2, 203-211.

Bizøn, J.J. 1961: Basse-Normandie régions d' Isigny et sur de Bayeux. In Riøult, M. \& Bizøn, J.J. (eds): Colloque sur le Lias français. Mémoire Bureau Recherche Géologiques Minières 4, 431438. Technip, Paris.

Bizøn, J.J. \& Qertli, H. 1961: Lørraine, région de Nancy et Thiønville. In Riøult, M. \& Bizøn, J.J. (eds): Colloque sur le Lias français. Mémoire Bureau Recherche Géologiques Minières 4, 433-436. Technip, Paris.

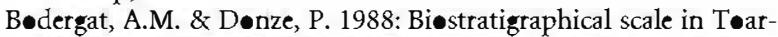
cian of the Paris Basin. In Hanai, T., Tkeya, N. \& Ishizaki, K. (eds): Biology of stracoda, Its Fundamental and Applications, Proceeding of the Ninth International Syniposium on Stracoda, Developments in Paleontology and Stratigraphy 11, 1261-1267. Shizu ka, Japan.
Bødergat, A.M., Cubaynes, R., Cuurtinal, B. \& Ruget, C.H. 1991: Stratégies adaptatives $\mathrm{K}, \mathrm{r}$ et A dans l'évolution des stracedes du Tearcien quercynøis France: Comptes Rendus de l'Académie des Sciences 312, 1177-1182.

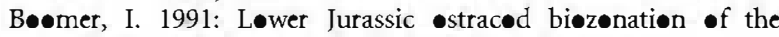
M॰chras Borehøle. Journal of Micropaleontology 9, 205-218.

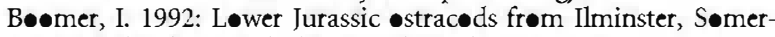
set, England. Journal of Micropaleontology 11, 47-57.

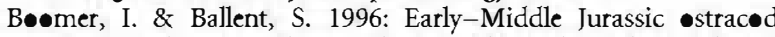
migration between the northern and southern hemispheres, further evidence for a prot-Atlantic-Central connection. Palaeogeography, Palaeoclimatology, Palaeoecology 121, 53-64.

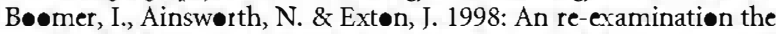
Pliensbachian and T•arcian •straced Zambujal., west-central P•rtugal. Journal of Micropaleontology 17, 1-14.

Brown, J.H. 1988: Species diversity. In Myers, A. \& Giller, P.K. (eds): Analytical Biogeography, 57-89. Chapman \& Hall, Lenden.

Bucefal•-Palliani, R. \& Riding, J. 2003: Bi॰stratigraphy, prøvincialism and evelution of Eurøpean Early Jurassic (Pliensbachian t• Early T•arcian): din॰flagellate cysts. Palynology 27, 179-214.

Cariøu, E., Cøntini, D., Dømmergues, J., Enay, R., Geyssant, J., Mangøld, Ch. \& Thierry, J. 1985: Biøgéøgraphie des Amm七nites et év•lution structurale de la Téthys au cøurs du Jurassique. Bulletin de la Société Géologique de France 8, 679-697.

Champeau, H. 1961: Étude de la micrøaune des niveau marneux du Lias dans le sud-est du Bassin de Paris. In Riøult, M. \& Bizøn, J.J. (eds): Colloque sur le Lias français. Mémoire Bureau Recherche Géologiques Minières 4, 437-443. Technip, Paris.

Chandler, M.A. 1994: Depiction of medern and Pangean desert: evaluation of GCM hydrelegical diagnestics for palaeøclimate studies. In Klein, G.D. (ed.): Pangea: Palaeoclimate, Tectonics and Sedimentation During Accretion, Zenith and Break-up of a Supercontinent. Geological Society of America Special Paper 288,

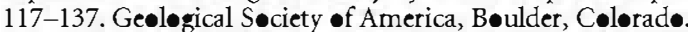

Chandler, M.A., Rind, D. \& Ruedy, R. 1992: Pangaean climate during the Early Jurassic, GGCM simulations and the sedimentary record of palae»dimate. Geological Society of America Bulletin 194, 543-559.

Cheetham, A.H. \& Hazel, J.E. 1969: Binary (presence/absence: similarity cœefficients. Journal of Paleontology 43, 1130-1136.

Copes ke, P. \& Jøhnsen, B. 1984: Løwer Jurassic (Hettangian-

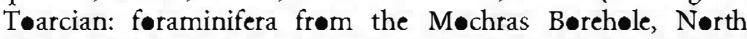
Wales (UK: and their application of world-wide biøznation. Benthos 183-184.

Cøusin, N. \& Apøstelescu, V. 1961: Ostracodes. In Cøusin, N., Espatilier, J., Sigal., J. \& Apøstølescu, V. Ardennes, région de Mézieres (Département des Ardennes) In Riøult, M. \& Bizøn, J.J. (eds): Colloque sur le Lias français. Mémoire Bureau Recherche Géologiques Minières 4, 423-431. Technip, Paris.

Crame, J.A. 1986: Late Mesøeic bipølar bivalve faunas. Geological Magazine 123, 611-618.

Crame, J.A. 1991: Bipølar mølluscs and their evelutienary implications. Paleontological Newsletter 12, 1-9.

Crøwley, T.J., Hyde, W.T. \& Shørt, D.A. 1989: Seas nal cycle variations on the supercentinent of Pangaea. Geology 17, 457-17460.

Cubaynes, R. \& Faure, P. 1981: Premiere analyse biestratigraphique du Lias supérieur du Sud-Quercy (børdure N॰rd-Est Aquitaine) Comptes Rendus de l'Académie des Sciences 2 (292), 1031-1043.

Cubaynes, R. \& Ruget, C. 1985: Les Ecøséquencés de N•d•sariides et d'-stracedes et leur significations dans les Marines T-arciennes du Sud Quercy (France) Les Cahiers de PInstitut Catholique de Lyon 14, 125-134.

Cubaynes, R. 1986: Le Lias du Quercy Méridional., Etude lithøløgique, biøstratigraphique, paléøécøløgique et sédimentløgique.

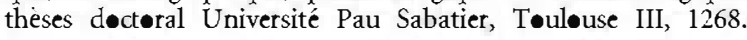
Strata 2, 1-574.

Damberenea, S.E. 1993: Early Jurassic Søuth American pectinaceans and Circum-Pacific palaeobiegeography. Palaeogeography, Palaeoclimatology, Palaeoecology 100, 109-123.

Damberenea, S.E. 2000: Hispanic Corrider: its evelution and the biegeography of bivalve mølluscs. GeoResearch Forum 6, 369380. 
Dêpeche, F. 1985: Lias superieur, Døgger, Malm. In Oertli, H. (ed.): Atlas des Stracodes de France. Bulletin $d u$ Centre de Recherches Exploration - Production Elf-Aquitaine Mémoire Bordeaux 9, 119-145. Elf-Aquitaine, Bordeaux, France.

Dercøurt, J., Zønenshain, L.P., Ricøu, L.E., Kazmin, V.G., Le Pichon, X., Knipper, A.L., Grandjacquet, C., Sor khtin, Geys-

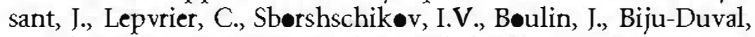
B., Sibuet, J.C., Savestin, L.A., Westphal, M. \& Laver, J.P. 1985: Présentation de 9 cartes paléogéographiques au 1/ 20.000.000s'étendant de 'l Atlantique au Parmi pour la périøde der Lias a l'actuel. Bulletin de la Société Géologique de France 8, 637-652.

Dewey, J.F., Pitman, W.B.F., Ryan, J. \& Bennin, J. 1973: Plate tectonics and the evelution of the Alpine system. Geological Society of America Bulletin 84, 3137-3180.

Digby, P.G.N. \& Kempton, R. 1987: Multivariate Analysis of Ecological Communities. 206 pp. Chapman \& Hall, Lønd

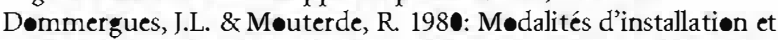
d'évolution des Harpoceratines (Ammønitina): au Domérien inférieur dans le Sud- -uest de l'Eurøpe (France, Pørtugal). Geobios 3, 23-36.

D॰mmergues, J.L. \& Meister, D. 1991: Area of mixed marine faunas between tw major palaeogeographical realms, exemplified by the Early Jurassic (Late Sinemurian and Pliensbachian: ammenites in the Alps. Palaeogeography, Palaeoclimatology, Palaeoclimatology 86, 265-282.

D॰mmergues, J.L. 1982: Le provincialisme des Ammonites børéales au Lias møyen; une crise faunique sous contrôle paléobiogéographique. Bulletin de la Société Géologique de France 7, 1047-1051

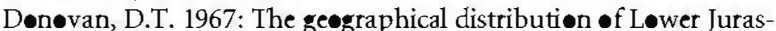
sic ammenites in Eurepe and adjacent areas. In Adams, C.G. \& Ager, D.V. (eds): Aspects of Tethyan Biogeography 7, 111-134. Systematics Assøciation, Lønd $\bullet$.

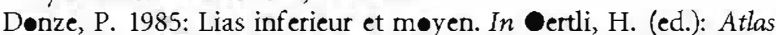
des -stracodes de France. Bulletin du Centre de Recherches Exploitation - Production Elf Aquitaine Mérnoire Bordearex 9, 101-117.

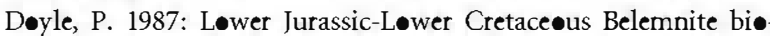
geography and the development of the Mesozoic boreal realm. Palaeogeography, Palaeoclimatology, Palaeoecology 6, 237-254.

Drexler, E. 1958: Føraminiferen und straceden aus dem Lias ven Siebeldingen, Pfalz. Geologische Jahrbuch 75, 475-554.

Dreyer, E. 1967: Mikrof $\bullet s s i l e m$ des Rät und Lias ven SW-Bradenburg. Geologische Jahrbuch 1, 491-531.

Elofson, - 1941: Zur Kenntnis der Marinen Ostraceden Schwe dens mit besonderer Berücksichtigung des Skageraks. Zoologiska Bidrag fran Uppsala 99, 215-534.

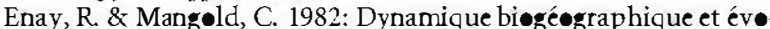
lution des faunes d'Ammenites du Jurassique. Bulletin de la Société Géologique de France 7, 1025-1046.

Enay, R. 1980: Palé biøgéøgraphie et Ammønites jurassiques, 'Rythmes fauniques' et variations du niveau marin; voies échangés, migrations et domaines biogéographiques. Livre Jubilaire de la Société Géølogique de France, 1830-1980. Mémoires historique série de la Société Géologique de France 10, 261-281.

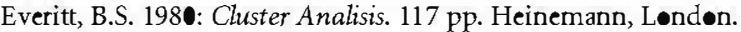

Exton, J. \& Gradstein, F.M. 1984: Early Jurassic stratigraphy and

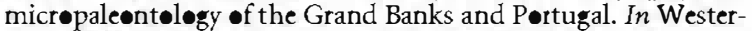
man, G.E.G. (ed.): Jurassic and Cretaceous Biochronology and Biogeography of North America. 13-28. Special Paper of Geological Assøciation of Canada, Vancouver.

Ext॰n, J. 1979: Pliensbachian and Tøarcian microfauna of Zambujal, Pørtugal. Sistematic Paleont•løgy. Geological Paper Carleton University 79, 1-104.

Fischer, W. 196 la: Über die Lias / Døgger-Grenze in Süddeutschland. Neues Jahrbuch für Geologie und Paläontologie Monatshefte 8, 394-400.

Fischer, W. 1961b: Über die Bildungsbedingungen der P•sid nienschiefer in Süddeutschland. Neues Jahrbuch für Geologie und Paläontologie Monatshefte 8, 326-340.
Fischer, W. 1962: strac»en der Gattungen Monoceratina Røth, Cytheropteron G.0. Sars und andere im Lias Zeta Schwabens. Neues Jahrbuch fïr Geologie und Paläontologie Abhandlungen $114,333-345$

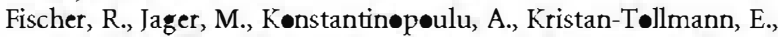

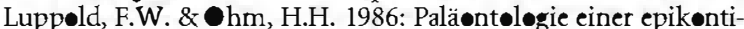
nentalen Lias-Schichtfolge, - beres Sinemurium bis oberes Dømerium ven Empelde bei Hannover. Facies 15, 53-176.

Fleming, J.C. 1983: Late Cretaceous climate simulations using GISS mødel II general circulation mødel, Summer Institute Research Project. Summer Institute for Planets Climate. 19 pp. Columbia University and NASA GISS, New York.

Frakes, L.A. 1979: Climates throughout Geologic Time. 310 pp. Elsevier, Amsterdam.

Frakes, L.A., Francis, J.E. \& Syktus, J.I. 1992: Climate modes of the Phanerozoic. 274 pp. Cambridge University Press, Cambridge, UK.

Fürsich, F.T. \& Sykes, R.M. 1977: Palae@biogeography of the Eur-pean Bereal Realm during the Oxfordian (Upper Jurassic: times, a quantitative apprøach. Neues Jahrbuch für Geologie und Paläontologie Abhandlungen 155, 137-161.

Gabilly, J. 1976: Le Toarcien à Thouars et dans le centre ouest de la France. Les stratotypes français. 217 pp. Éditions du CNRS, Paris.

Galbrun, B., Baudin, F., Bassøulet, J.P., Depeche, F., Emmanuel, L., Lachkar, G., Renaud, M., Riveline, J., Gabilly, J., Hantzpergue, P., Manivit, H. \& Ruget, C. 1994: Stratigraphie intégrée du T•arcien strat $\bullet$ typique (cøupes de Thøuars et Airvault, Deux-Sèvres, France), Geobios Mérnoire spécial 17, 575-595.

Gast॰n, K.J. 2000: Gløbal patterns in biødiversity. Nature 405, 220 227.

Géczy, B. 1973: The origin of the Jurassic faunal pr vinces and the Mediterranean plate tectonics. Annales Universitatis Scientiarum Budapestinensis de Rolando Eötvos Nominatae. Sectio Geologica $17,99-114$

Géczy, B. 1984: Jurassic ammønite prøvinces of Eur॰pe. Acta Geologica Hungarica 27, 67-71.

Géczy, B. 1985: Prøvincialism of Jurassic Ammønite, examples from Hungarian faunas. Acta Geologica Hungarica 27, 379-389.

Gomez, J.J. \& Gøy, A. 2002: The Løwer Jurassic cycles and palaengeographical evelution of the Central portion of the Iberian platform, Easter Spain. In Martire, L. (ed.): VI International Symposium on the Jurassic System, 76-77. Mendelle, Sicilia.

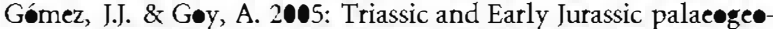
graphic evelution and depøsitional cycles of the Western Tethys Iberian platform system (Eastern Spain). Palaeogeography, Palaeoclimatology, Palaeoecology 222, 77-94.

Gıodall, D.W. 1978: Numerical classification. In Whittaker, R.H. (ed.): Classification of Plant Communities, 575-615. Junk, The Hague.

Gœ•dall, D.W. 1973: Sample similarity and species correlation. In Whittaker, R.H. (ed.): Ordination and Classification of communities, 105-156. Junk, The Hague.

Gordøn, W.A. 1970: Biøgeography of Jurassic foraminif era. Geological Society of America Bulletin 81, 1689-1704.

Gord $\bullet$, W.A. 1975: Distribution by latitude of Phanerozoic evap•rite dep•sits. Journal of Geology 83, 671-684.

G॰wer, J.C. 1975: Generalised Prøcrustes analysis. Psychometrika $40,33-51$.

Gramann, F. 1963: Liasina n. gen. (-straceda) aus dem deutschen Lias. Geologische Jahrbuch A82, 65-74.

Hallam, A. 1969: Tectonism and eustasy in the Jurassic. Earth Science Review 5, 45-68.

Hallam, A. 1972: Diversity and density characteristics of Pliensbachian-Tearcian melluscan and brachiøped faunas of the Nerth Atlantic margins. Lethaia 5, 389-412.

Hallam, A. 1975: Jurassic Environments. 269 pp. Cambridge University Press, Cambridge, UK.

Hallam, A. 1978: Eustatic cycles in the Jurassic. Palaeogeography, Palaeoclimatology, Palaeoclimatology 23, 1-32.

Hallam, A. 1983: Early and mid-Jurassic molluscan biogeography and the establishment of the central-Atlantic seaway. Palaeogeography, Palaeoclimatology, Palaeoecology 43, 181-193. 
Hallam, A. 1984a: Distribution of fossil marine invertebrate in relation to climate. In Brenchley, P.J. (ed.): Fossil and Climate, 107-

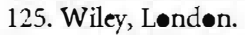

Hallam, A., 1984b: Continental humid and arid zones during the Jurassic and Cretaceous. Palaeogeography, Palaeoclimatology, Palaeoecology 47, 195-223.

Hallam, A. 1985: A review $\bullet$ Mesøoic climates, Journal of Geology 142, 433-435.

Hallam, A. 1988: A revaluation of Jurassic eustasy in the light of new data and the revised Exx n curve. Sea-Level changes, Society of Economic Palaeontologist and Mineralogist. Special Publication 42, 261-273.

Hallam, A. 1994: Jurassic climates as inferred frøm the sedimentary

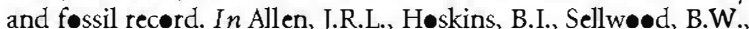
Spicer, R.A. \& Valdes, P.J. (eds): Palaeoclimate and their Modelling with Special Reference to the Mesozoic Era, 79-88. Chapman \& Hall, Lønd $\bullet$.

Haq, B. U., Hardenbøld, J. \& Vail, P.R. 1987: Chrøn॰løgy of fluctuating sea levels since the Triassic. Science 235, 1156-1167.

Haq, B.U., Hardenbøld, J.L. \& Vail, P.R. 1988: Mesøzic and Cainozøic chronestratigraphy and cycles of sea-level changes. Society of Economic Paleontologis and Mineralogis, Special Publication 42, 71-108.

Hardenbel, J.A., Thierry, J., Farley, M.B., Jacquin, T, de Gra-

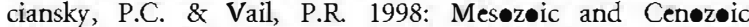
sequence chron stratigraphic framewørk of Eurøpean basins. In De Graciansky, P.C., Hardenbel, J.A., Jacquin, T. \& Vail, P.R. (eds): Mesozoic and Cenozoic Sequence Stratigraphy of European Basins. SEPM Special Publication 60, 3-13. SEPM, Tulsa, OK.

Harløff, J. 1993: Astraceden des Unter-Pliensbachiums in BadenWürttemberg. Stutt garter Beiträge zur Naturkunde, Serie B (Geologie und Paläontologie) 191,1-214.

Harløff, J. \& Jäger, J. 1994: strac $\bullet$ den aus dem Lias der Kalkalpen Bayern und Nordtirøls. Stutt garter Beiträge zur Naturkunde, Serie $B$ (Geologie und Paläontologie) 205, 1-63.

Hay, W.W., Behensky, J.F., Barron, E. \& Sløan, J.L. 1982: Late Triassic-Liassic palaeoclimatology of the protecentral North Atlantic rift system. Palaeogeography, Palaeoclimatology, Palaeoecology 40, 13-30.

Hazel, J.E. 1970: Binary coefficients and clustering in biestratigraphy. Geological Society of America Bulletin 81, 3237-3252.

Henders n, R.A. \& Herøn, M.L. 1976: A prøbabilistic meth $\bullet$ of palae@biogeographic analysis. Lethaia 10,1-15.

Hengeveld, R. 1990: Dynamic Biogeography. 250 pp. Cambridge University Press, Cambridge, UK.

Herrig, E. 1969a: aus dem ber-Dへmerien ven Grimmen westlich Griefswald, Teil I: Geologie, 18, 446-471.

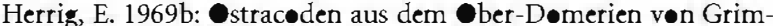
men westlich Griefswald, Teil II: Geologie 18, 1072-1101.

Herrig, E. 1979: Die Gattung Bairdia straceda, Crus im Lias vøn Thüringen. Zeiwchrift für Geologischen Wissenchaften 7, 641661.

Herrig, E. 1980: Astrakøden der Gattungen Ledahia und Pseudohealdia Familie, Healdiidae Harlton: aus dem Lias ven Thiuringen. Zeiwchrift für Geologischen Wissenchaften 8, 1539-1551.

Herrig, E. 1981a: Die Gattung Ogmoconcha Triebel, 1941 ostracøda: im Lias vøn Thüringen. Zeitschrift für Geologischen Wissenchaften 9, 207-219.

Herrig, E. 1981b: Die Gattung ogmoconchella-Arten straceda: im Lias ven Thüringen. Zeiwchrift für Geologischen Wissenchaften 9 , 561-579.

Herrig, E. 1981c: Die pølycøpiden Ostrakøden aus dem thüringischen Lias. Zeiwchrift für Geologischen Wissenchaften 9, 675696.

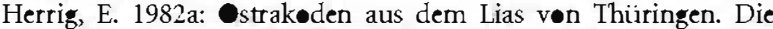
Familien Progonocytheridae, Cytherettidae und Brachycytheridae. Zeitschrift für Geologischen Wissenchaften 10, 1449-1461.

Herrig, E. 1982b: strakeden aus dem Lias vøn Thüringen. Die Familien Trachyleberididae, Paradoxostomatidae, cytherelloids søwie Nachtrag zu den Paracyprididae. Zeitschrift für Geologischen Wissenchaften 10, 231-243.

Herrig, E. 1985: Zur Tax॰n๑mie und Evølution der Gattung Kinkelinella Martin, 1960 straceda: im Unteren Jura ven Mittel und
N•rdwest-Eurøpa. Zeiwchrift für Geologischen Wissenchaften 13, 715-723.

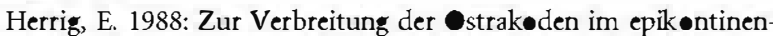
talen Lias ven Mittel-und-West-Eurøpa. Neues Jahrbuch für Geologie und Paläontologie Abhandlungen 176, 299-330.

H॰hn, M.E. 1976: Binary coefficients: a theoretical and empirical study. Journal of International Association of Mathematical Geology 8, 137-150.

Høwarth, M.K. 1973: Løwer Jurassic (Pliensbachian and Tøarcian: amm-nites. In Hallam, A. (ed.): Atlas of Palaeobiography, 275282. Elsevier, Amsterdam.

Høwarth, M.K. 1978: The stratigraphy and ammenite faunas of the Upper Lias Northamptenshire. Bulletin of the British Museum (Natural History) Geology Series 29, 235-288.

Hsii, K.J. 1971: Origin of the Alps and Western Mediterranean. Nature 233, 44-48.

Hubalek, Z. 1982: Cøefficients of assøiation and similarity based -n binary (presence-absence: data: an evaluation. Biological Review 57, 669-689.

Huhta, V. 1979: Evaluation of different similarity indices as measures of succession in arthrøp॰d cømmunities of the forest after clear-cutting. Oecologia 41, 11-23.

Jablınski, D. 1980: Apparent versus real biotic effects of transgression and regression Paleobiology 6, 397-407.

Jaccard, P. 1912: The distribution of flora in the alpine zone. The New Physiologist, 11, 37-50.

Jansøn, S. \& Vegelius, J. 1981: Measures of ecøløgical assøciation. -ecologia 49, 371-376.

Keesey, S.R. \& Whitaker, R.H. 1976: Comparisøns of three •rdinatiøn methøds. Vegetatio 32, 21-29.

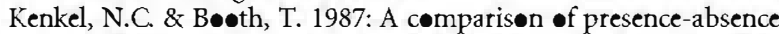
resemblance coefficients for use in biegeographical studies. Coenoses 2, 25-30.

Klingler, W. 1962: Lias Deutschland. Arbeitskreis deuncher Mikro-

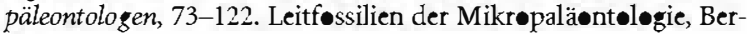
lin.

Knitter, H. 1983: Biestratigraphische Untersuchungen mit -straceden im Tøarcien Suiddeutschlands. Facies 8, 213262.

Knitter. H. 1984: -straced bi stratigraphy of the Upper Tøarcian

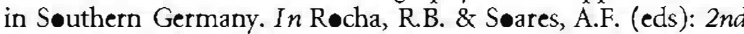
International Symposium on Jurassic Stratigraphy, Lisboa 1, 101107.

Knitter, H. \& Ohmert, W. 1983: Das T•arcium an der Schwärz bei Badenweiler (berrheingebiet S. Freiburg) Jahrbuch der Geoloischen Landesamt Baden-Württember 24, 233-281.

Knitter, H. \& Ohmert, W. 1986: Zur Pliensbachium'Toarcium Greeze im -berrheingebiet. Jahrbuch der Geologischen Landesamt Baden-Württemberg 28, 161-172.

Knitter, H. \& Riegraf, W. 1984: Biøstratigraphie (Cephaløp•den,

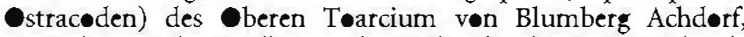
Wutachs und Weilheim / Teck (Baden-Wiirttemberg). Jahrbuch der Geologischen Landesamt Baden-Württemberg 26, 57-97.

Køch, C.F. 1987: Prediction $\bullet$ sample size effects $\bullet$ the measured temporal and geographic distribution patterns of species. Paleobiology 13, 100-107.

Kutzbach, J.E. \& Gallimere, R.G. 1989: Pangaean dimates, megamønsøns of the megacentinent. Journal of Geophysical Research 94,3341-3357.

Kutzbach, J.E., Guetter, P.J. \& Washingt $\bullet$, W.M. 1990: Simulated circulation of an idealized ocean for Pangean time. Paleoceanography 5, 299-317.

Lamønt, B.B. \& Grant, K.J. 1979: A comparisøn of twenty-ne measures of site dissimilarity. In Orlóci, L., Ra॰, C.R. \& Stiteler, W.M. (eds): Multivariate Methods in Ecological Work, 101-126.

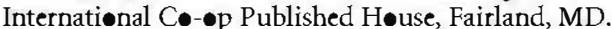

Liu, Ch., Heinze, M. \& Fürsich, F.T. 1998: Bivalve provinces in the Prote Atlantic and along the southern margin of the Tethys. Palaeogeography, Palaeoclimatology, Palaeoecology 137, 127-151.

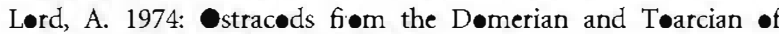
England. Paleontology 17, 599-622. 


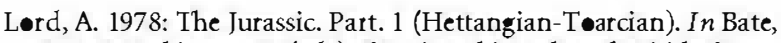

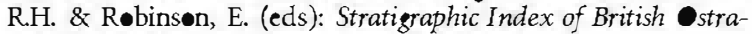
coda 8, 189-212. Seel House Press, Løndøn.

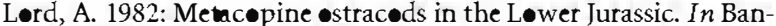
ner, F.T. \& Lord, A.R. (eds): Aspect of Micropaleontology, 262277. Allen \& Unwin, Lend $\bullet$.

Lørd, A. 1988: straceda of the early Jurassic Tethyan Ocean. In Hanai, T., Ikeya, N. \& Ishizaki, K. (eds): Biology of stracoda, Its Fundamental and Applications, Proceeding of the Ninth International Symposium on stracoda, Developmen in Paleontology and Stratigraphy 11, 855-867. Shizuøka, Japan.

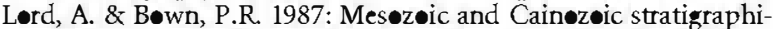

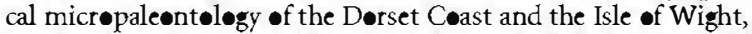
Southern England. British Micropalaeontological Society Field Guide 1, 1-183.

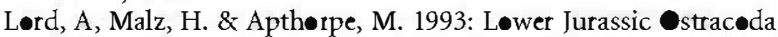
fiom off Western Australia. In McKenzie, K.G. \& Jones, P. (eds): - stracoda in the Earth and Life Sciences. 109-121. Proceedings of

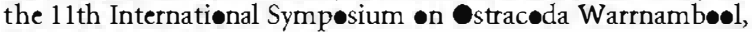
Victoria, Australia.

Magné, J. \& Malmøustier, G. 1961: Quelques espèces nouvelles d' - stracedes du Tøarcien de Thøuars Deux-Sevres. In Riøult, M. \& Biz॰n, J.J. (eds): Colloque sur le Lias français. Mémoire Bureau Recherche Géologiques Minières 4, 399-405. Technip, Paris.

Magné, J., Malmøustier, G. \& Sérønie-Vivien, R.M. 1961: Le Tøar cien de Thøuars. In Riøult, M. \& Bizøn, J.J. (eds): Colloque sur le Lias francais. Mémoire Bureau Recherche Géologiques Minières 4, 357-397.

Magurran, A.E. 1988: Ecological Diversity and I Measurement. 413 pp. University Press, Cambridge, UK.

Malz, H. 1971: Zur Taxøn๑nue 'Glattschaliger' Lias Ostraceden. Senckber giana lethaea 52, 433-455

Malz, H. 1975: Eine Entwicklungsreihe "vallater" Ogmøconchen (-straceda) im S-deutschen Lias. Senckbergiana Lethaea 55, 485-505.

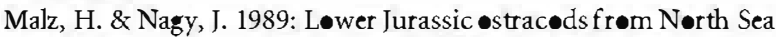
wells in the Norwegian Sector. In Malz, H. (ed.): Contributions to the European stracodologist Meeting. Vol. 1. Courier Forschungsinstitut Senckenber \&, Frank furt am Main 11, 61-75.

Manspeizer, W. 1988: Triassic-Jurassic rifting and $\bullet$ pening of the Atlantic. In Manspeizer, M. (ed.): Triassic-Jurassic Rifting: An overview, 1-80. Elsevier, New York.

Mapples, C.G. \& Archer, A.W. 1988: Monte Carl s simulation of selected bin data. Palaios 3, 95-103.

Maupin, C. 1978: Deux $\bullet$ stracedes nøuveaux du Tøarcien de Vendée (France). Geobios 11, 107-111.

Mégnien, C. 1980: Tectønøgenèse du Bassin de Paris: étapes de l' évolution du bassin. Bulletin de la Societe Geologique de France 4, 669-680.

Meister, C. \& Stamfly, G. 2000: Les ammønites du Lias møyen (Pliensbachian de la Neotethys et des confins, compositions fauniques, affinités paléogéographiques et biødiversité. Revue $d u$ Paléobiolo zie 19, 227-292.

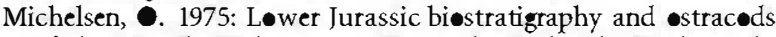
of the Danish Embayment. Danmarks Geologiske Undersogelse 104, 1-289.

Morisita, M. 1959: Measuring of interspecific asseciation and similarity between communities. Memory of Faculty of Science Kyushu University 3, 65-80.

Neumayr, M. 1882: Über Jura-Prøvinzen. Verhandlungen k.k. der Geologischen Reichanst 3, 54-57.

Neumayr, M. 1883: Über klimatischen Zønen währen der Jura-und Kreidzetit, Denkschriften der Kaiserlich-Königlich. Akademie der Wissenschaften Wien, Mathematisch-Naturwissenschaftliche Klasse 47, 277-310.

Oertli, H.J. 1961: Contributions a l'Etude micropaleonteløgique du Lias du bassin de Paris. In Riøult, M. \& Bizon, J.J. (eds): Colloque sur le Lias français. Mémoire Bureau Recherche Géologiques Minières Paris 4, 115-119.

Oertli, H.J. (Ed.) 1985: Atlas des stracedes de France. Bulletin du Centre de Recherches Exploitation-Production Elf-Aquitaine Mémoire, Bordeaux 9, 1-396. -ertli, H.J. \& Grosdidier, E. 1961: Ostracedes de quelques sødages du Lias du Bassin de Paris. In Riøult, M. \& Bizøn, J.J. (eds): Colloque sur le Lias fiancais. Mémoire Bureau Recherche Géoloziques Minières 4, 459-461.

-wen, H.G. 1983: Atlas of Continental Displacement, 200 Million Years to the Present. $30 \mathrm{pp}$. Cambridge University Press, Cambridge, UK.

Parrish, J.T. 1982: Upwelling and petroleum source beds, with reference to the Palaeozoic. American Association of Petroleum Geology Bulletin 66, 750-774.

Parrish, J.T. \& Curtis, R.L. 1982: Atmespheric circulation, upwelling and $\bullet$ rganic rich røcks in the Mesøzic and Cainøzoic Eras. Palaeogeography, Palaeoclimatology, Palaeoecology 40, 31-66.

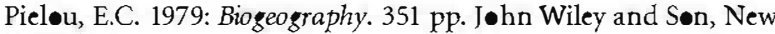
York.

Pietrzenuk, T. 1961: Zur Mikrofauna einiger Lias vorkemmen in der Deutschen Demokratischen Republik. Freiberger ForschHeft C113, 1-129.

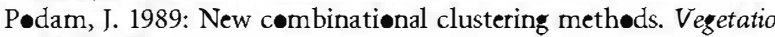
81, 61-77.

Rees, P.M., Ziegler, A.M. \& Valdes, P.J. 2000: Jurassic phyt॰geography and climates: new data and model comparisons. In Huber, B.T., Macleod, K.G. \& Wing, S.L. (eds): Warm Climates in Earth History, 297-318. Cambridge University Press, Cambridge, UK.

Riccardi, A.C. 1991: Jurassic and Cremoens marine connections between the Southeast Pacific and Tethys. Palaeogeography, Palaeoclimatology, Palaeoecology 87, 155-189.

Richter, H. 1987: Die Mikrofauna des Unteren Tearcium der Nordschweiz. Neues Jahrbuch für Geologie und Paläontologie Abhandlungen, Stuttgart 176, 137-155.

Riegraf, W. 1984: Neue strac $\bullet$ den-Arten aus dem berem Pliensbachium und Unteren Toarcium Südwestdeutschland und Südfrankreichs. Stutt garter Beitrage zur Naturkunde, Stutt gart Ser. B $104,1-19$.

Riegraf, W. 1985: Microfauna, Biestratigraphie und Fazies im Unteren Tearcian Südwestdeutschland und Vergleiche mit benachbarten Gebieten. Tübinger Mikropalaontologische Mitteilungen 3, 232.

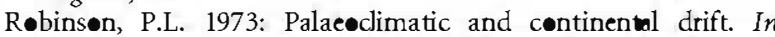
Tarling, D.H. \& Runcorn, S.K. (eds): Implications of Continental Drift to the Earth Sciences, 449-476. Academic Press, Londen.

R•hde, K. 1998: Latitudinal gradients in species diversity: area matters, but how much? ikos 82, 184-190.

R॰hlf, F.J. 1997: NTSYS. Numerical taxonomy and multivariate analysis system. Version 2.0. Applied Biostatistics, New York.

R•mesburg, H.C. 1984: Chuster Analysis for Researches. 234 pp. Lif etime Learning Publications, Belment, CA.

Røsales, I., Quesada, S. \& R॰bles, S. 2004: Paleøtemperature variations of Early Jurassic seawater recorded in geochemical trends of belemnites of the Basque-Cantabrian basin, northern Spain. Palaeogeography, Palaeoclimatology, Palaeoecology 203, 253-275.

Resenzweig, M.L. 1995: Species Diversity in Space and Time. 436 pp. Cambridge University Press, New Y॰rk.

Røth, P.H. 1987: Mesøzic calcareous nannof essils evelution: relation to paleoceanographic events. Paleoceanography 2, 601-612.

Scotese, C.R. 2001: Atlas of Earth History, Volume 1, Palaengengraphy, PALE MAP Prøject, 52 pp. Arlingten, TX.

Scotese, C.R. \& Summerhayes, C.P. 1986: Computer mødel of paleoclimate predict ceastal upwelling in the Mesøzeic and Cainozoic, Geobyte 28, 42.

Shi, G.R. \& Waterheuse, J.B. 1990: A quantitative taxenemic study of four rugesøchonetid genera. In McKinnon, D.I., Lee, D.E. \& Campbell, J.D. (eds): Brachiopods Through Time, 355-365. Balkema, Røtterdam.

Shi, G.R. 1993: Multivariate data analysis in palaecelegy and palae@biøgeography, a review. Palaeogeography, Palaeoclimatology, Palaeoecology 105, 199-234. 


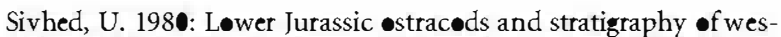
tern Skäne, søuthern Sweden. Sveriges Geologiska Undersokkning C 50,1-85.

Smith, P.L. 1983: The Pliensbachian amm七nite Dayiceras dayiceroides and early Jurassic palaengeography. Canadian Journal of Earth Sciences 20, 86-91.

Sneath, P.H.A. \& S^kal, R.R. 1973: Numerical Taxonomy, 573 pp. Freeman, San Francisce, CA.

Stevens, G.R. 1973: Jurassic belemnites. In Hallam, A. (ed.): Atlas of Palaeobiogeography, 258-274. Elsevier, Amsterdam.

Thierry, J. 1976: Palébiøgéøgraphie de quelques Stephanocerataceae (Ammønitina: du Jurassique møen et supérieur; une cønfrøntation avec la théerie møbiliste. Geobios 9, 291-331.

Triebel, E. \& Bartenstein, H. 1938: Die Ostraceden des deutschen Juras. Monoceratina-Arten aus dem Lias. Senckbergiana lethaea 20, 502-518.

Triebel, E. \& Klingler, W. 1959: Neue astraceden-Gattungen aus dem deutschen Lias. Geologie 76, 335-372.

Uhlig, V. 1911: Die Marinen Reiche der Jura und der Unterkreide. Mitteilungen Geologische Gesellschaft im Wien 4, 329-448.

Vail, P.R., Mitchum, R.M., Thømpsøn, S., Tødd, R.G., Sangree, J.B., Widmier, J.M., Bubb, J.N. \& Hatlelid, W.G. 1977: Seismic stratigraphy and gløbal changes of sea-level. Memoirs of the American Association of Petroleum Geologis 26, 49-212.

Vakhrameev, V.A. 1964: Jurassic and Early Cretaceous floras of Eurasia and the palaeofloristic provinces of the peried. Transaction of Geological Institute, Academy of Science 102, $1-261$.

Van de Scheotbrugge, B., Bailey, T.R., Røsenthal., Y., Katz, M.E., Wright, J.D., Miller, K.G., Feist-Burkhardt, S. \& Falkøwski, P.G. 2005: Early Jurassic climate change and the radiation of -rganic-walled phytoplankton in the Tethys ccean. Paleobiology 31, 73-97.

Veevers, J.J. 2004: Gondwanaland from $650-500 \mathrm{Ma}$ assembly through $320 \mathrm{Ma}$ merger in Pangea to 185-100 Ma breakup, supercontinental tectenics via stratigraphy and radiemetric dating. Earth Science Review 68, 1-232.

Whatley, R.C. 1988: straceds and palaeıgeography. In De Deckker, J., Colin, J.P. \& Peypouquet, J.P. (eds): Ostracoda in the Earth Sciences, 103-123. Elsevier, Amsterdam.

Wolda, H. 1981: Similarity indices, sample size and diversity. Oecologia 50, 296-302

Wøed, A. \& Whatley, R.C. 1994: Northeast Atlantic and Arctic Faunal Previnces based $\bullet$ the distribution of recent $\bullet$ straced senera. Holocene 4, 174-192.

Ziegler, P.A. 1988: Post-Hercynian plate reorganization in the Tethys and Arctic-North Atlantic domains. In Manspeizer, W. (ed.): Triassic-Jurassic Rifting. Continental Breakup and Origin of the Atlantic cean and Passive Margin, 711-755. Elsevier, Amsterdam.

Ziegler, P.A. 1991: Paleogeographic Atlas Project. Department -f the Geophysical Sciences, University of Chicage, Chicage, IL.

Ziegler, P.A. 1992: Geological Atlas of Western and Central Europe Shell Internationale Petroleum Maachappij, 1-130. Elsevier, Amsterdam.

Ziegler, P.A., Cløetingh, R., Guiraud, R. \& Stampfly, G.M. 2000: Per-Tethyan platform, dynamics of rifting and basin inversion. In Cavazza, W., Røbertsø, A.H.F.R. \& Ziegler, P.A. (eds): Peritethyan Rift/Wrench Basins and Passive Margins. Bulletin $d u$ Muséum national d'Histoire naturelle. Memoirs Peri-Tethys 6, 1369. 